\title{
Compensatory Changes in the Noradrenergic Nervous System in the Locus Ceruleus and Hippocampus of Postmortem Subjects with Alzheimer's Disease and Dementia with Lewy Bodies
}

\author{
Patricia Szot, Sylvia S. White, J. Lynne Greenup, James B. Leverenz, Elaine R. Peskind, and Murray A. Raskind \\ Northwest Network for Mental Illness Research, Education, and Clinical Center, Veterans Administration Puget Sound Health Care System, Seattle, \\ Washington 98108, and Department of Psychiatry and Behavioral Science, University of Washington, Seattle, Washington 98195
}

In Alzheimer's disease (AD), there is a significant loss of locus ceruleus (LC) noradrenergic neurons. However, functional and anatomical evidence indicates that the remaining noradrenergic neurons may be compensating for the loss. Because the noradrenergic system plays an important role in learning and memory, it is important to determine whether compensation occurs in noradrenergic neurons in the LC and hippocampus of subjects with $\mathrm{AD}$ or a related dementing disorder, dementia with Lewy bodies (DLB). We observed profound neuronal loss in the LC in AD and DLB subjects with three major changes in the noradrenergic system consistent with compensation: (1) an increase in tyrosine hydroxylase (TH) mRNA expression in the remaining neurons; (2) sprouting of dendrites into peri-LC dendritic zone, as determined by $\alpha_{2}$-adrenoreceptors (ARs) and norepinephrine transporter binding sites; and (3) sprouting of axonal projections to the hippocampus as determined by $\alpha_{2}$-ARs. In AD and DLB subjects, the postsynaptic $\alpha_{1}$-ARs were normal to elevated. Expression of $\alpha_{1 \mathrm{~A}^{-}}$and $\alpha_{2 \mathrm{~A}^{-}} \mathrm{AR}$ mRNA in the hippocampus of AD and DLB subjects were not altered, but expression of $\alpha_{1 \mathrm{D}^{-}}$and $\alpha_{2 \mathrm{C}^{-}} \mathrm{AR}$ mRNA was significantly reduced in the hippocampus of AD and DLB subjects. Therefore, in AD and DLB subjects, there is compensation occurring in the remaining noradrenergic neurons, but there does appear to be a loss of specific AR in the hippocampus. Because changes in these noradrenergic markers in AD versus DLB subjects were similar (except neuronal loss and the increase in TH mRNA were somewhat greater in DLB subjects), the presence of Lewy bodies in addition to plaques and tangles in DLB subjects does not appear to further affect the noradrenergic compensatory changes.

Key words: norepinephrine; Alzheimer's disease; in situ hybridization; adrenoreceptors; locus ceruleus; hippocampus

\section{Introduction}

In Alzheimer's disease (AD), a substantial loss of noradrenergic cell bodies has been documented in postmortem brain tissue in the locus ceruleus (LC), the major source of noradrenergic projections to the whole brain (Mann et al., 1980; Tomlinson et al., 1981; Bondareff et al., 1982; Marcyniuk et al., 1986; Chan-Palay and Asan, 1989; German et al., 1992). However, studies in patients with $\mathrm{AD}$ and several postmortem brain tissue studies suggest that the surviving noradrenergic neurons may partially compensate for LC neuronal loss in AD. CSF concentrations of norepinephrine (NE) and its metabolites do not differ in the early stages of $\mathrm{AD}$ from those of healthy older individuals and may increase as AD progresses (Mann et al., 1981; Gottfries et al., 1983; Raskind et al., 1984; Tohgi et al., 1992; Elrod et al., 1997).

\footnotetext{
Received 0ct. 6, 2005; revised Nov. 9, 2005; accepted Nov. 14, 2005.

These studies were supported by the Department of Veterans Affairs Research and Development Services, Northwest Network Mental IIIness Research, Education, and Clinical Center, and Alzheimer's Disease Research Center.

Correspondence should be addressed to Dr. Patricia Szot, Northwest Network for Mental IIIness Research, Education, and Clinical Center (116), Puget Sound Health Care System, 1660 South Columbian Way, Seattle, WA 98108. E-mail: szot@u.washington.edu.

DOI:10.1523/JNEUROSCI.4265-05.2006

Copyright $\odot 2006$ Society for Neuroscience $\quad$ 0270-6474/06/260467-12\$15.00/0
}

The content of NE in terminal regions such as the neocortex and hippocampus in postmortem $\mathrm{AD}$ subjects is reduced, but the reduction does not correspond to the degree of neuronal loss in the LC (Adolfsson et al., 1979; Mann et al., 1981; Tomlinson et al., 1981; Palmer et al., 1987; Reinikainen et al., 1988; Hoogendijk et al., 1999). A similar result was observed when the synthesizing enzymes for NE were measured in forebrain regions (Cross et al., 1981; Perry et al., 1981; Palmer et al., 1987; Russo-Neustadt et al., 1998). Recently, our laboratory demonstrated a significant increase in the mRNA expression for the rate limiting enzyme tyrosine hydroxylase $(\mathrm{TH})$ in the LC of $\mathrm{AD}$ subjects (Szot et al., 2000), suggesting that the remaining neurons in the LC are compensating for the loss of noradrenergic neurons of $\mathrm{AD}$ subjects.

Because the noradrenergic system has been shown to play a major role in learning and memory (Gibbs and Summers, 2002), it is important to determine whether compensatory changes are occurring in the noradrenergic nervous system in $\mathrm{AD}$ subjects. In addition, we have evaluated a related dementing disorder, dementia with Lewy bodies (DLB). The approach was twofold: (1) to examine the noradrenergic nervous system in the $\mathrm{LC}$ and then (2) to examine the noradrenergic system in the hippocampus, another region critical for learning and memory (Morris et al., 
2003). In the LC, we measured the expression of TH mRNA and binding sites to the $\alpha_{2}$-adrenoreceptor (AR) autoreceptor and NE transporter (NET) that are localized to the dendrites of these neurons. In the hippocampus, we measured the $\alpha_{1}$ - and $\alpha_{2}$-AR binding sites, as well as the mRNA for each of the subtypes for each of the $\alpha_{1}$ - and $\alpha_{2}$-AR receptors in the LC $\left(\alpha_{2 \mathrm{~A}}-\mathrm{AR}\right)$ and hippocampus ( $\alpha_{1 \mathrm{~A}^{-}}, \alpha_{1 \mathrm{D}}, \alpha_{2 \mathrm{~A}^{-}}$, and $\left.\alpha_{2 \mathrm{C}^{-}} \mathrm{AR}\right)$. The results of these studies indicate that the remaining noradrenergic neurons in $\mathrm{AD}$ and DLB subjects show changes in the LC and at terminal projection regions that are consistent with compensation for neuronal loss.

\section{Materials and Methods}

Subjects. All postmortem tissue was obtained from the Alzheimer's Disease Research Center, where permission for use of tissue in scientific experiments was obtained. AD is characterized by the insidious onset and gradual progression of impaired memory, language, and executive function. Psychosis, agitation, and other behavioral disturbances characteristically appear late in the disease course. DLB, which accounts for $\sim 20 \%$ of patients with late-life dementia, presents early in its course with psychotic symptoms such as visual hallucinations and with fluctuating cognition and pronounced attentional deficits and often with bradykinesia and increased muscle tone (McKeith et al., 1996; Ballard et al., 1999; Barber et al., 2001). The AD subjects used in these studies met the National Institute on Aging Reagan criteria for AD (Braak stage IV/C or higher with no vascular dementia, frontotemporal dementia, or Lewy body pathology) (McKhann et al., 1984) (Table 1). DLB subjects used in these studies met the same neuropathological diagnostic criteria (Table 1) for $\mathrm{AD}$ plus had the presence of Lewy body pathology in the brainstem and limbic regions as confirmed by $\alpha$-synuclein immunohistochemistry. Medical records of control subjects indicated no clinical, neurological, or psychiatric illness or evidence of cognitive or functional decline and had no obvious neuropathology during autopsy. Subjects who had been diagnosed with depression before death or had taken any antidepressant medication were excluded because depression and antidepressant therapy can result in changes in brain noradrenergic system (Lacroix et al., 1991; Bauer and Tejani-Butt, 1992; Harro and Oreland, 2001; Ordway et al., 2003). Subjects with a history of alcohol or drug abuse were also excluded. Table 1 contains pathology information as well as age, postmortem delay (PMD), and sex for each of the subjects. Hippocampus was studied in the following: 17 nondemented age-comparable control subjects, with an age range of 38-90 years (mean \pm SEM, $71.4 \pm 3.5$ years), seven males and 10 females with an average PMD of $8.5 \pm 0.9 \mathrm{~h} ; 15 \mathrm{AD}$ subjects with an age range of 37-94 years (mean \pm SEM, $68.6 \pm 4.4$ years), six males and nine females with an average PMD of $7.4 \pm 0.9 \mathrm{~h}$; and 22 DLB subjects with an age range of 63-98 years (mean \pm SEM, $79.5 \pm 1.6$ years), 16 males and six females with an average PMD of $8.0 \pm$ $0.7 \mathrm{~h}$. Because the LC was not always obtained at the time of autopsy, the number of subjects for control and DLB groups was 15, and they are indicated in Table 1.

Tissue. Left hemispheric hippocampal tissue was accessed at autopsy using a protocol that provided the complete hippocampus (unilaterally) in snap-frozen blocks. The fresh medial temporal tissue block for each individual was dissected into 1-cm-thick coronal blocks, snap frozen in liquid nitrogen-cooled isopentane, and stored at $-70^{\circ} \mathrm{C}$. Serial coronal dorsal hippocampal sections $(20 \mu \mathrm{m})$ at the level of the lateral geniculate were cut on a cryostat, thaw mounted onto FisherSuper frost slides, and stored at $-70^{\circ} \mathrm{C}$ for each individual.

LC tissue was accessed at autopsy using a protocol that provided the complete LC (bilaterally) in a snap-frozen block of caudal midbrain and rostral brainstem. The block included the region between the third nerve in the midbrain to the trigeminal nerve in the pons. The block was dissected into three horizontal blocks, frozen in liquid nitrogen-cooled isopentane, and stored at $-70^{\circ} \mathrm{C}$. Serial horizontal sections $(20 \mu \mathrm{m})$ from the three blocks were cut on a cryostat, thaw mounted onto FisherSuper frost slides, and stored at $-70^{\circ} \mathrm{C}$. The rostral-to-caudal distance of the LC was determined for each case by examining sections every $500 \mu \mathrm{m}$ stained with thionin. The rostral (or $0 \%$ ) was defined as the beginning of
Table 1. Specifics on neuropathology, age, PMD, sex, and whether LC was available for each subject

\begin{tabular}{|c|c|c|c|c|c|}
\hline Subject & Braak & PMD (h) & $\begin{array}{l}\text { Age } \\
\text { (years) }\end{array}$ & Sex & $\mathrm{LC}$ \\
\hline Control & NA & 13 & 38 & $\mathrm{~F}$ & No \\
\hline Control & I-A & 16 & 52 & $\mathrm{~F}$ & Yes \\
\hline Control & I-0 & 10 & 55 & M & Yes \\
\hline Control & I-A & 10 & 55 & M & Yes \\
\hline Control & II-B & 15 & 60 & $\mathrm{~F}$ & Yes \\
\hline Control & $0-A$ & 12 & 69 & M & Yes \\
\hline Control & ?-B & 6 & 70 & $\mathrm{~F}$ & Yes \\
\hline Control & I-B & 11 & 73 & $M$ & Yes \\
\hline Control & NA & 8 & 77 & $\mathrm{~F}$ & Yes \\
\hline Control & $\mathrm{I}-0$ & 4 & 78 & $M$ & Yes \\
\hline Control & II-B & 5 & 78 & $M$ & No \\
\hline Control & $\mathrm{I}-0$ & 9 & 80 & $\mathrm{~F}$ & Yes \\
\hline Control & II-B & 5 & 84 & $\mathrm{~F}$ & Yes \\
\hline Control & II-B & 6 & 84 & $M$ & Yes \\
\hline Control & II-0 & 5 & 85 & $\mathrm{~F}$ & Yes \\
\hline Control & III-C & 5 & 85 & $\mathrm{~F}$ & Yes \\
\hline Control & II-C & 5 & 90 & $\mathrm{~F}$ & Yes \\
\hline$A D$ & V-C & 7 & 37 & $M$ & Yes \\
\hline$A D$ & V-C & 16 & 44 & $\mathrm{~F}$ & Yes \\
\hline$A D$ & V-C & 6 & 45 & $\mathrm{~F}$ & Yes \\
\hline$A D$ & VI-C & 4 & 55 & $M$ & Yes \\
\hline$A D$ & V-C & 6 & 61 & $\mathrm{~F}$ & Yes \\
\hline$A D$ & NA & 14 & 66 & $M$ & Yes \\
\hline$A D$ & VI-C & 6 & 70 & $\mathrm{~F}$ & Yes \\
\hline$A D$ & VI-C & 4 & 74 & $M$ & Yes \\
\hline$A D$ & V-C & 4 & 74 & $\mathrm{~F}$ & Yes \\
\hline$A D$ & VI-C & 4 & 75 & $\mathrm{~F}$ & Yes \\
\hline$A D$ & V-C & 10 & 80 & $\mathrm{~F}$ & Yes \\
\hline$A D$ & VI-C & 10 & 81 & $M$ & Yes \\
\hline$A D$ & V-C & 7 & 83 & $M$ & Yes \\
\hline$A D$ & V-C & 7 & 90 & $\mathrm{~F}$ & Yes \\
\hline$A D$ & IV-C & 6 & 94 & $\mathrm{~F}$ & Yes \\
\hline DLB & V-C & 8 & 63 & $M$ & Yes \\
\hline DLB & V-C & 5 & 67 & M & Yes \\
\hline DLB & VI-C & 12 & 68 & M & Yes \\
\hline DLB & IV-C & 17 & 70 & $M$ & Yes \\
\hline DLB & V-C & 5 & 75 & $M$ & Yes \\
\hline DLB & V-C & 15 & 75 & $M$ & Yes \\
\hline DLB & V-C & 6 & 77 & $\mathrm{~F}$ & Yes \\
\hline DLB & V-C & 7 & 78 & $M$ & Yes \\
\hline DLB & IV-C & 7 & 79 & $M$ & Yes \\
\hline DLB & V-C & 9 & 79 & $M$ & Yes \\
\hline DLB & V-C & 10 & 79 & $M$ & Yes \\
\hline DLB & V-C & 5 & 80 & $M$ & No \\
\hline DLB & VI-C & 7 & 81 & $\mathrm{~F}$ & Yes \\
\hline DLB & V-C & 9 & 82 & $\mathrm{~F}$ & No \\
\hline DLB & VI-C & 10 & 82 & M & No \\
\hline DLB & V-C & 6 & 83 & M & Yes \\
\hline DLB & V-C & 4 & 84 & $M$ & No \\
\hline DLB & V-C & 4 & 85 & $M$ & No \\
\hline DLB & V-C & 5 & 85 & $\mathrm{~F}$ & Yes \\
\hline DLB & V-C & 12 & 86 & $M$ & No \\
\hline DLB & VI-C & 6 & 88 & $\mathrm{~F}$ & Yes \\
\hline DLB & VI-C & 8 & 98 & $\mathrm{~F}$ & No \\
\hline
\end{tabular}

NA, Not available.

the trochlear nucleus, and the caudal pole (100\%) ended at the rostral level of the trigeminal motor nucleus (Hoogendijk et al., 1999). After the rostral-to-caudal distance of the LC was determined for each case, sections were systematically taken to include the 30,50 , and $70 \%$ levels of the LC because the rostral portion of the LC innervates forebrain structures such as the hippocampus, whereas the caudal portion of the LC innervates hindbrain structures such as the cerebellum and spinal cord (Fallon and Loughlin, 1982; Loughlin et al., 1982). 
TH mRNA. Tissue preparation and labeling of the TH oligonucleotide probes was performed as described previously for oligonucleotide labeling (Szot et al., 1997). TH mRNA expression was measured only in the LC, the main loci for noradrenergic innervation throughout the CNS. For each subject, three consecutive slides at the 30,50, and 70\% levels of the LC were labeled with the TH mRNA oligonucleotide probe. The TH probe consisted of three separate oligonucleotide probes to the following nucleotides of the published human sequence (O'Malley et al., 1987) (GenBank accession number X05290): 326-377, 520-571, and 13091360. The oligonucleotide probes were $3^{\prime}$ end labeled with $\left[{ }^{33} \mathrm{P}\right] \mathrm{dATP}$ (PerkinElmer, Boston, MA) using terminal deoxyribonucleotidyl transferase (Invitrogen, Piscataway, NJ). The TH probe contained $2.0 \times 10^{6}$ $\mathrm{cpm} / 50 \mu \mathrm{l}$ and was washed as described in detail in previously published work with oligonucleotides (Szot et al., 1997). Slides were apposed to film (Eastman Kodak, Rochester, NY) for $4 \mathrm{~d}$ at room temperature, and then the slides were coated with NTB2 Nuclear Track Emulsion (undiluted) (Eastman Kodak) and stored at $-20^{\circ} \mathrm{C}$ for $14 \mathrm{~d}$. Film and slides were developed as described previously (Szot et al., 1997).

Quantitation of TH mRNA expression was similar to that performed by Szot et al. (2000). The number of cells that achieved labeling threefold higher than background was counted bilaterally on the three slides at each level of the LC for each subject and expressed as TH-positive labeled cell \pm SEM. Data were analyzed with ANOVA, followed by a post hoc Fisher's test; statistical significance was taken at $p<0.05$. The density of TH mRNA expression per cell was performed measuring the amount of silver grains over the cell bodies of labeled neurons that were threefold higher than background under $20 \times$ dark-field illumination with a sidemounted light using the MicroComputer Imaging Device system (MCID) (Imaging Research, St. Catharines, Ontario, Canada). Therefore, all labeled neurons that were counted as positive labeled were also quantitated for the amount of TH mRNA expression per cell. The data are expressed as the average of grains per cell \pm SEM bilaterally at each level of the LC for each subject group. Statistical analysis was performed as described above.

$\alpha_{2 \mathrm{~A}}$-AR mRNA. Tissue preparation and labeling of the $\alpha_{2 \mathrm{~A}}$-AR oligonucleotide probes was performed as described previously for oligonucleotide labeling (Szot et al., 1997). $\alpha_{2 \mathrm{~A}}$-AR mRNA was measured in the LC at the three different levels of the LC as described for TH mRNA and in the dorsal hippocampus. Three consecutive slides were used for each level of the LC and in the dorsal hippocampus. The $\alpha_{2 \mathrm{~A}}$-AR probe consisted of three separate oligonucleotide probes to the following nucleotides of the published human sequence (Kobilka et al., 1987; Fraser et al., 1989): 951-1001, 1071-1121, and 1303-1353. The $\alpha_{2 \mathrm{~A}}$-AR probe contained $1.3 \times 10^{6} \mathrm{cpm} / 50 \mu \mathrm{l}$ for the hippocampus and $0.8 \times 10^{6} \mathrm{cpm} / 50$ $\mu \mathrm{l}$ for the LC. Slides were apposed to film (Eastman Kodak) for $7 \mathrm{~d}$ at room temperature for hippocampus, whereas slides containing the LC were coated with NTB2 Nuclear Track Emulsion (undiluted) (Eastman Kodak) and stored at $-20^{\circ} \mathrm{C}$ for $14 \mathrm{~d}$. Film and slides were developed as described previously (Szot et al., 1997).

Quantitation of $\alpha_{2 \mathrm{~A}}$-AR mRNA expression in the LC was identical to the method used to quantitate TH mRNA expression. In the hippocampus, optical density (OD) measurements were taken from labeling observed on film using MCID as described previously (Szot et al., 1997). ODs were obtained from films using MCID. Separate OD measurements were made over the three sections for each subject. Background OD was subtracted from each image. The data are expressed as the average OD \pm SEM for each region for each subject group. Statistical analysis was performed as described above.

$\alpha_{2 C^{-}} A R m R N A$. Tissue preparation and labeling of the $\alpha_{2 C^{-A R} \text { oligo- }}$ nucleotide probes was performed as described previously for oligonucleotide labeling (Szot et al., 1997). $\alpha_{2 \mathrm{C}}$-AR mRNA was measured in the dorsal hippocampus. Preliminary work in the LC showed $\alpha_{2 C}$-AR mRNA levels to be undetectable. Three consecutive slides of the dorsal hippocampus were used. The $\alpha_{2 \mathrm{C}}$-AR probe consisted of a single oligonucleotide probe to the following nucleotides of the published human sequence (Lomasney et al., 1990): 875-925. The $\alpha_{2 \mathrm{C}}$-AR probe contained $0.16 \times 10^{6} \mathrm{cpm} / 50 \mu \mathrm{l}$ for the hippocampus. Slides were apposed to film (Eastman Kodak) for $17 \mathrm{~h}$ at room temperature. Film was developed and

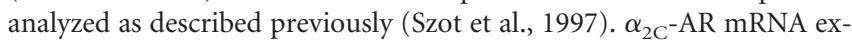

pression in the hippocampus was measured as OD using MCID as described for $\alpha_{2 \mathrm{~A}}$-AR mRNA in the hippocampus. The data are expressed as the average OD \pm SEM for each region for each subject group. Statistical analysis was performed as described above.

$\alpha_{1 A}$-AR mRNA. Tissue preparation and labeling of the $\alpha_{1 \mathrm{~A}}$-AR oligonucleotide probes was performed as described previously (Szot et al., 2005). $\alpha_{1 \mathrm{~A}}$-AR mRNA was measured in the dorsal hippocampus. Three consecutive slides of the dorsal hippocampus were used. The $\alpha_{1 \mathrm{~A}}$-AR probe consisted of three separate oligonucleotide probes to the following nucleotides of the published human sequence (Schwinn et al., 1990; Hirasawa et al., 1993): $1-45,1102-1156$, and 1435-1483. The $\alpha_{1 \mathrm{~A}}$-AR probe contained $1.4 \times 10^{6} \mathrm{cpm} / 50 \mu \mathrm{l}$ for the hippocampus. Slides were apposed to film (Eastman Kodak) for $4 \mathrm{~d}$ at room temperature. Film was developed and analyzed as described previously (Szot et al., 1997). $\alpha_{1 \mathrm{~A}}$-AR mRNA expression in the hippocampus was measured as OD using MCID. The data are expressed as the average OD \pm SEM for each region for each subject group. Statistical analysis was performed as described above.

$\alpha_{1 D}-A R$ mRNA. Tissue preparation and labeling of the $\alpha_{1 \mathrm{D}}$-AR oligonucleotide probes was performed as described previously (Szot et al., 2005). $\alpha_{1 \mathrm{D}}$-AR mRNA was measured in the dorsal hippocampus. Three consecutive slides of the dorsal hippocampus were used. The $\alpha_{1 \mathrm{D}}$-AR probe consisted of three separate oligonucleotide probes to the following nucleotides of the published human sequence (Weinberg et al., 1994; Schwinn et al., 1995): 587-635, 990-1038, and 1668-1716. The $\alpha_{1 \mathrm{D}}$-AR probe contained $0.4 \times 10^{6} \mathrm{cpm} / 50 \mu \mathrm{l}$ for the hippocampus. Slides were apposed to film (Eastman Kodak) for $7 \mathrm{~d}$ at room temperature. Film was developed and analyzed as described previously (Szot et al., 1997). $\alpha_{1 \mathrm{D}}$-AR mRNA expression in the hippocampus was measured as OD using MCID. The data are expressed as the average OD \pm SEM for each region for each subject group. Statistical analysis was performed as described above.

${ }^{3} \mathrm{H}$-Prazosin and ${ }^{125}$ I-HEAT binding $\left(\alpha_{1}-A R\right) . \alpha_{1}$-AR binding sites were measured in the hippocampus with two different radiolabeled compounds, ${ }^{3} \mathrm{H}$-prazosin and ${ }^{125} \mathrm{I}$-HEAT $\left[( \pm)-\beta\right.$ - $\left[{ }^{125} \mathrm{I}\right.$-iodo-4-hydroxyphenyl]-ethyl-aminomethyl-tetralone] (PerkinElmer). ${ }^{3} \mathrm{H}$-Prazosin binding was performed as described previously (Szot et al., 2005). For each subject, four consecutive slides, each containing a section of the dorsal hippocampus was run: three slides for total binding and the fourth for nonspecific binding. Briefly, slides were thawed at room temperature for $10 \mathrm{~min}$, and then $400 \mu \mathrm{l} /$ slide of incubation buffer $\left(\sim 0.2 \mathrm{nM}{ }^{3} \mathrm{H}\right.$ prazosin in $50 \mathrm{~mm}$ Tris buffer with $1 \mathrm{~mm}$ EDTA, $\mathrm{pH}$ 7.4) was placed over the tissue. Slides were incubated for $40 \mathrm{~min}$ at room temperature and then washed twice for $2 \mathrm{~min}$ in ice-cold $50 \mathrm{~mm}$ Tris buffer, $\mathrm{pH}$ 7.4, dipped in ice-cold distilled water to remove the salts, and then rapidly dried under a stream of cool air. Nonspecific binding was defined in the presence of $10 \mu \mathrm{m}$ phentolamine. Slides and ${ }^{3} \mathrm{H}$ standards were apposed to Biomax MR film (Eastman Kodak) for 8 weeks. Films were developed and analyzed as described previously (Szot et al., 1997). Density measurements (microcuries per gram) were determined using MCID unilaterally in the dorsal hippocampus, and the values are expressed as a mean (microcuries per gram) \pm SEM for each subject group. Specific binding was obtained by taking the total average value minus nonspecific value in the same region. Specific binding for ${ }^{3} \mathrm{H}$-prazosin constituted $\sim 90 \%$ of total binding. Statistical analysis was performed as described above.

Receptor binding with ${ }^{125}$ I-HEAT was performed according to Homma et al. (2000). For each subject, four consecutive slides, each containing a section of the dorsal hippocampus, was run: three slides for total binding and the fourth for nonspecific binding. Slides were thawed as described above, and then $400 \mu \mathrm{l} /$ slide of incubation buffer $(\sim 100 \mathrm{pM}$ ${ }^{125} \mathrm{I}$-HEAT in $50 \mathrm{~mm}$ Tris buffer with $150 \mathrm{~mm} \mathrm{NaCl}$ and $5 \mathrm{~mm}$ EDTA, pH 7.4) was placed over the tissue. Slides were incubated for $60 \mathrm{~min}$ at room temperature and then washed as described above for ${ }^{3} \mathrm{H}$-prazosin. Nonspecific binding was defined in the presence of $10 \mu \mathrm{M}$ phentolamine. Slides were apposed to Biomax MS film (Eastman Kodak) for $4 \mathrm{~h}$. Films were developed as described previously (Szot et al., 1997). Autoradiograms were quantified using MCID and expressed as OD. Specific binding was determined as described above. Specific binding for ${ }^{125} \mathrm{I}$-HEAT constituted $\sim 30 \%$ of total binding. 
${ }^{3} \mathrm{H}$-Nisoxetine binding (NET). NET binding sites were measured in the LC with ${ }^{3} \mathrm{H}$ nisoxetine (American Radiolabeled Chemicals, St. Louis, MO) according to Bauer and TejaniButt (1992). Preliminary work indicated the hippocampus to not have detectable levels of NET binding sites. From each subject, four consecutive slides from the 30,50 , and $70 \%$ of the LC were run: three slides for total binding and the fourth for nonspecific binding. Slides were thawed as described above, and then $400 \mu \mathrm{l} /$ slide of incubation buffer $\left(\sim 3 \mathrm{~nm}{ }^{3} \mathrm{H}-\right.$ nisoxetine in $50 \mathrm{~mm}$ Tris buffer with $300 \mathrm{~mm}$ $\mathrm{NaCl}$ and $5 \mathrm{~mm} \mathrm{KCl}, \mathrm{pH}$ 7.7) was placed over the tissue. Slides were incubated for $90 \mathrm{~min}$ at room temperature and then washed as described above for ${ }^{3} \mathrm{H}$-prazosin. Nonspecific binding was defined in the presence of $1 \mu \mathrm{M}$ mazindol. Slides were apposed to Biomax MR film (Eastman Kodak) for 8 weeks. Films were developed as described previously (Szot et al., 1997). Density measurements (microcuries per gram) were determined as described above using ${ }^{3} \mathrm{H}$ standards and MCID. Specific binding was obtained by taking the total average value minus nonspecific value in the same region. Specific binding for ${ }^{3} \mathrm{H}$-nisoxetine constituted $60-70 \%$ of total binding. Statistical analysis was performed as described above.

${ }^{3} H$-RX821002 binding $\left(\alpha_{2}-A R\right) . \alpha_{2}$-AR binding sites were measured in the LC and hippocampus with ${ }^{3} \mathrm{H}-\mathrm{RX} 821002$ (PerkinElmer) according to Happe et al. (2004). For each subject, four consecutive slides from the 30,50 , and $70 \%$ of the LC and four consecutive sections from the dorsal hippocampus were run as described above. Slides were thawed as described above, and then $400 \mu \mathrm{l} /$ slide of incubation buffer $\left(\sim 2 \mathrm{nM}{ }^{3} \mathrm{H}-\mathrm{RX} 821002\right.$ in $50 \mathrm{mM} \mathrm{NaPO}_{4}$ buffer, $\mathrm{pH}$ 7.4) was placed over the tissue. Slides were incubated for $45 \mathrm{~min}$ at room temperature and then washed twice for $2 \mathrm{~min}$ in ice-cold $50 \mathrm{~mm} \mathrm{NaPO}_{4}$ buffer, $\mathrm{pH}$ 7.4, dipped in ice-cold distilled water to remove the salts, and then rapidly dried under a stream of cool air. Nonspecific binding was defined in the presence of $10 \mu \mathrm{M}$ rauwolscine. Slides were apposed to Biomax MR film (Eastman Kodak) for 8 weeks. Films were developed as described previously (Szot et al., 1997). Density measurements and statistical analysis were obtained as described above for ${ }^{3} \mathrm{H}$-prazosin. Specific binding for ${ }^{3} \mathrm{H}$-RX821002 constituted $\sim 90 \%$ of total binding.

\section{Results}

None of the noradrenergic parameters measured in this study correlated to the age or sex of the subject or to the PMD. However, we observed significant effects of disease status on noradrenergic parameters as described below.

TH mRNA expression is elevated in the remaining neurons in the $\mathrm{LC}$ of $\mathrm{AD}$ and DLB subjects

Figure 1 shows the dark-field photomicrographs of TH mRNA expression over cell bodies in the LC of control $(A), \mathrm{AD}(B)$, and DLB $(C)$ subjects as defined by cresyl violet staining and the presence of melanin. Quantitation of the number of TH mRNApositive cell bodies in AD and DLB indicated a significant reduction from control subjects at the 30,50, and 70\% levels of the LC (Fig. 1D). The loss of TH-positive labeled neurons in AD is similar to DLB subjects at the 30 and 50\% levels of the LC; however, at the $70 \%$ level of the LC, DLB subjects had a significantly greater loss of TH mRNA-positive neurons than $\mathrm{AD}$ subjects. In contrast, there was a significant increase in the amount of TH mRNA expression per cell body in all three levels of the LC in both $\mathrm{AD}$ and DLB subjects (Fig. 1E). At the 30 and $70 \%$ levels of the LC, the amount of TH mRNA expression per cell body was the same between $\mathrm{AD}$ and DLB subjects, but, at the $50 \%$ level of the LC, DLB subjects had an even greater increase in TH mRNA expression per cell compared with the AD subjects.

A comparison of the number of TH-positive labeled cells to the Clinical Dementia Ratings of AD and DLB subjects showed a significant negative correlation to exist at the 30,50 , and $70 \%$ levels of the LC $(r=-0.653, p<0.001 ; r=-0.571, p<0.01 ; r=$ $-0.588, p<0.01$, respectively). This indicates that the loss of TH-positive labeled cells in the LC correlated to the loss of cognitive function in AD and DLB.

A significant negative correlation also existed between the number of TH-positive cells to the amount of TH mRNA expression per cell body at each of the three different levels of the LC (30\% level, $r=-0.391, p<0.01 ; 50 \%$ level, $r=-0.325, p<$ 0.05 ; 70\% level, $r=-0.463, p<0.01)$, indicating that the subjects with the fewest number of TH-positive cells in the LC had the greatest amount of TH mRNA expression per cell. Therefore, the remaining noradrenergic neurons in the LC of AD and DLB subjects appear to be compensating by increasing the expression of the rate-limiting enzyme in the synthesis of NE, and this occurs throughout the LC. 

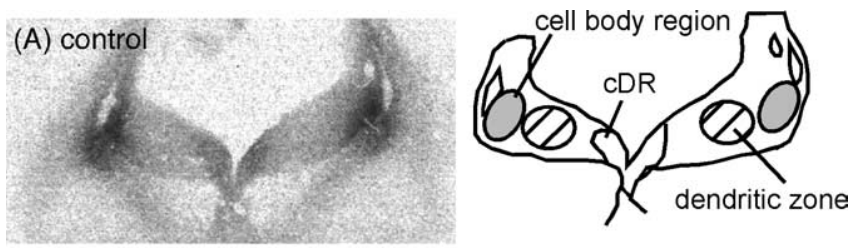

(B) $A D$
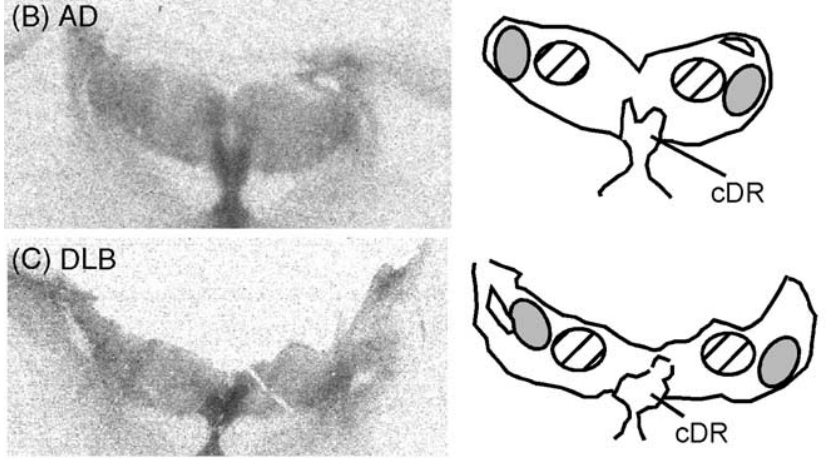

(D)

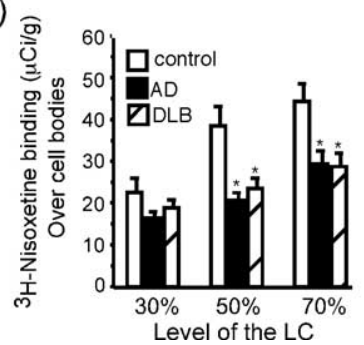

(E)

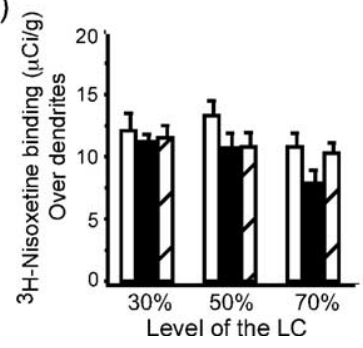

Figure 2. NET binding sites in the $\mathrm{LC}$ and $\mathrm{CDR}$ of control $(\boldsymbol{A})(n=15), \mathrm{AD}(\boldsymbol{B})(n=15)$, and $\operatorname{DLB}(C)(n=15)$ subjects at the $50 \%$ level. The left side of the figure is the autoradiograms of ${ }^{3} \mathrm{H}$-nisoxetine binding in the $\mathrm{LC}$ and $\mathrm{CDR}$. The right side outlines the area labeled by ${ }^{3} \mathrm{H}-$ nisoxetine in the $L C$, the gray shaded area indicates where the $L C$ cell bodies are located, and the cross-hatched area indicates where the peri-LC dendritic zone is located. Quantification of NET binding sites over the $L(C$ cell body region ( $\boldsymbol{D}$; gray shaded area on $\boldsymbol{A}-\boldsymbol{C}$ ) and quantification of NET over the peri- $\mathrm{L}\left(\mathrm{dendritic}\right.$ area $(\boldsymbol{E}$; cross-hatched area on $\boldsymbol{A}-\boldsymbol{C})$ are shown. ${ }^{*}$ Significant difference compared with control subjects. Data are represented as mean \pm SEM.

\section{NET binding sites are reduced over LC cell body region but normal over the peri-LC dendritic zone and caudal dorsal raphe}

NET is localized to noradrenergic neurons, and its function is to remove released NE from the synapse. NET binding sites, as measured by ${ }^{3} \mathrm{H}$-nisoxetine, were localized to the LC cell body region and the peri- LC dendritic zone, as well as the caudal dorsal raphe region (cDR) (Fig. 2A-C). Quantitation of NET binding sites over the cell body plus peri-LC dendritic zone indicated a significant decrease in NET binding sites at the 50 and $70 \%$ levels of the LC in AD and DLB subjects compared with control subjects (data not shown). The loss of NET binding sites in AD and DLB at these levels of the LC were similar. To determine whether the loss of NET binding sites was specific to just the cell body region, density measurements were taken specifically over the cell body region (Fig. 2A-C, gray shaded area) and the peri-LC dendritic zone (Fig. $2 A-C$, cross-hatched shaded area). Quantification of NET binding sites over the LC cell body region showed a significant reduction in the $\mathrm{AD}$ and $\mathrm{DLB}$ subjects compared with control subjects at the 50 and $70 \%$ levels of the LC (Fig. 2D). Again the loss of NET binding sites over the LC cell body region is similar between $\mathrm{AD}$ and $\mathrm{DLB}$ subjects. This would suggest that neuronal number in the LC could contribute to the loss of NET binding sites. Correlation studies partially support this theory. At the $30 \%$ level in the LC, a significant correlation was observed between

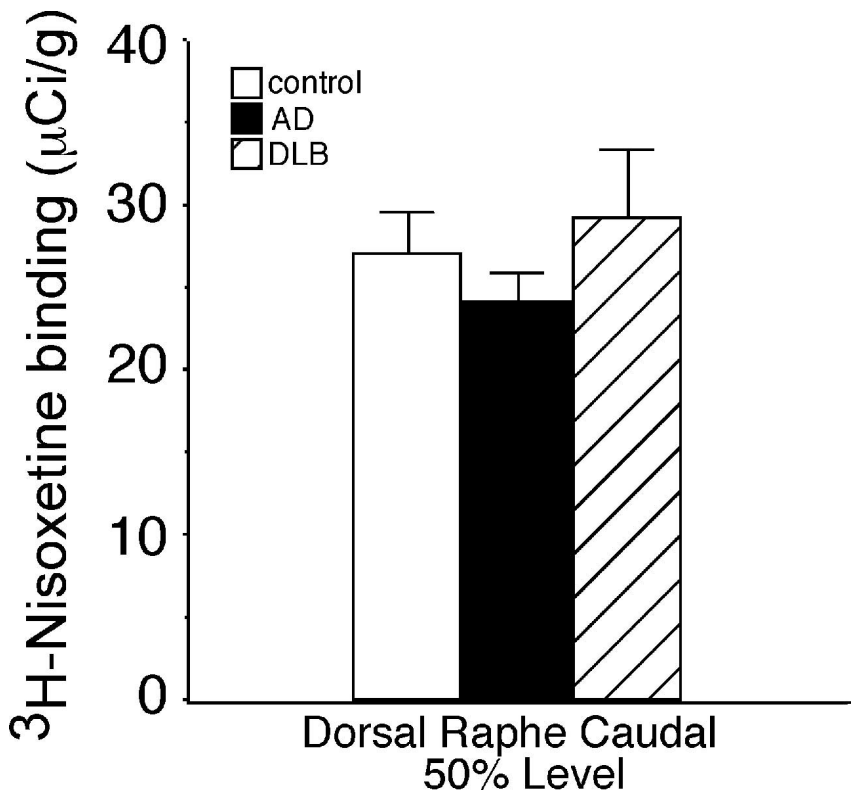

Figure 3. Quantification of NET binding sites in the $C D R$ at the $50 \%$ level of the $L C$ in control $(n=15), \mathrm{AD}(n=15)$, and DLB ( $n=15)$ subjects. Autoradiographic images can be seen in Fig. $2 A-C$. Data are represented as mean \pm SEM.

NET binding sites over cell body region and the number of THpositive labeled cells in control, $\mathrm{AD}$, and DLB subjects $(r=0.666$, $p<0.01 ; r=0.64, p<0.05 ; r=0.715, p<0.01$, respectively). However, at the $50 \%$ level of the LC, only the AD and DLB had a significant correlation to TH-positive labeled neurons $(r=0.772$, $p<0.01 ; r=0.834, p<0.01$, respectively), and, at the $70 \%$ level of the LC, none of the groups displayed a correlation to THpositive labeled neurons. These data suggests that the loss of noradrenergic neurons in the LC in AD and DLB may account for the loss of NET binding sites at the 30 and 50\% levels of the LC but not at the $70 \%$ level of the LC. However, it is unclear what contributes to this loss of NET binding sites.

Quantitation of NET binding sites over the peri-LC dendritic zone was not statistically different between the three subject groups (Fig. 2E), despite the loss of TH-positive labeled neurons. This suggests that the remaining noradrenergic neurons in $\mathrm{AD}$ and DLB subjects may be demonstrating dendritic sprouting as a means to maintain connections in the peri-LC dendritic area that would have been lost with the reduction of noradrenergic neurons. Axonal sprouting from the remaining neurons also appears to have occurred because the amount of NET binding sites in the $\mathrm{CDR}$ in $\mathrm{AD}$ and $\mathrm{DLB}$ subjects were not different from controls (Fig. 3).

$\alpha_{2}$-AR binding sites in AD and DLB subjects are normal at the $30 \%$ level of the LC to modestly reduced at the 50 and $70 \%$ levels of the LC

The localization of $\alpha_{2}$-AR binding sites, as measured by the $\alpha_{2}$-AR antagonist ${ }^{3} \mathrm{H}-\mathrm{RX} 821002$ (Fig. $4 A-C$ ), were similar to that observed with ${ }^{3} \mathrm{H}$-nisoxetine (Fig. $2 A-C$ ). However, unlike ${ }^{3} \mathrm{H}$-nisoxetine in the LC, ${ }^{3} \mathrm{H}-\mathrm{RX} 821002$ was not statistically greater over the cell body region compared with the peri-LC dendritic zone (data not shown). Quantitation of $\alpha_{2}$-AR binding sites over cell body region plus peri-LC dendritic area (Fig. $4 A-C$, dashed circular area) indicated a significant reduction in $\mathrm{AD}$ and DLB subjects at the $50 \%$ level of the LC and in DLB subjects alone at the $70 \%$ level of the LC compared with control subjects (Fig. 

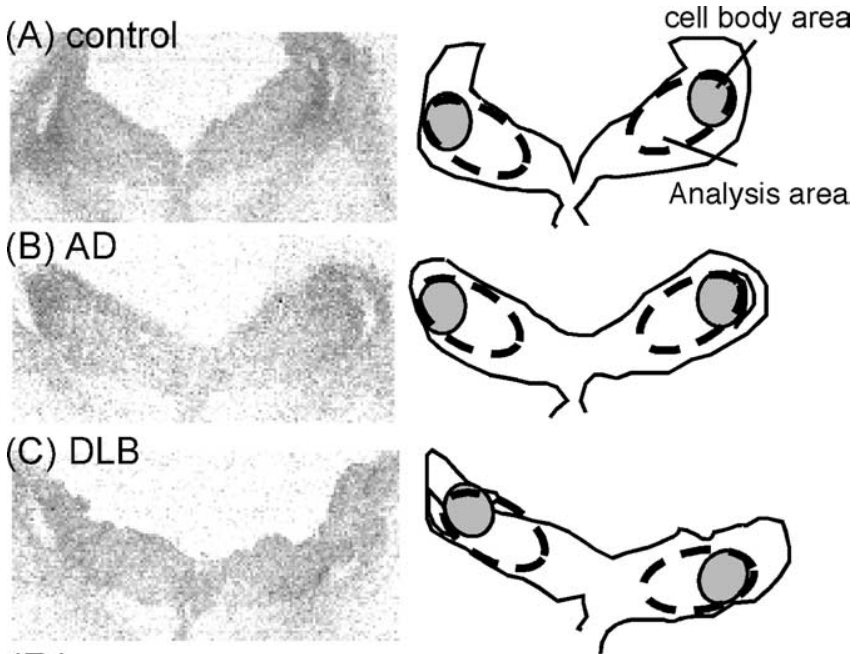

(D)

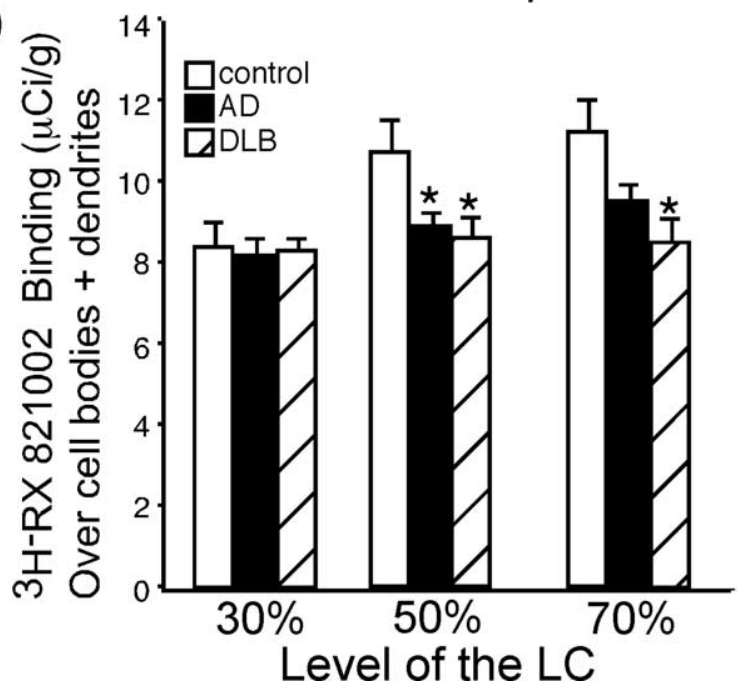

Figure 4. $\quad \alpha_{2}$-AR binding sites in the $\mathrm{LC}$ at the $50 \%$ level of control $(\boldsymbol{A})(n=15), \mathrm{AD}(\boldsymbol{B})(n=$ $15)$, and $\operatorname{DLB}(\boldsymbol{C})(n=15)$ subjects. The left side of the figure is the autoradiograms of ${ }^{3} \mathrm{H}-$ $\mathrm{RX} 821002$ binding in the LC. The right side outlines the area labeled by ${ }^{3} \mathrm{H}-\mathrm{RX} 821002$ in the LC, and the gray shaded area indicates where the $L C$ cell bodies are located in relation to binding area. D, Quantification of $\alpha_{2}$-AR binding sites in the LC at the 30,50, and 70\% levels in control, $A D$, and DLB subjects (dashed circular area). * Significant difference compared with control subjects. Data are represented as mean \pm SEM.

$4 D)$. The loss of $\alpha_{2}$-AR binding sites in the LC between AD and DLB subjects was not statistically different at any level of the LC. $\alpha_{2}$-AR binding sites in control, AD, or DLB subjects at the three different levels of the LC did not correlate to TH-positive labeled neurons in the LC, as observed with NET binding sites in the cell body region. This indicates that the loss of $\mathrm{TH}$-positive neurons in the LC of $A D$ and DLB was not responsible for the reduction in binding sites. This was evident at the $30 \%$ level of the LC in which there was a tremendous loss of $\mathrm{TH}$-positive neurons in the LC ( $\sim 80 \%$ loss), but the amount of $\alpha_{2}$-AR binding was the same between the three subjects groups. At the 50 and $70 \%$ levels of the $\mathrm{LC}$, the loss of TH-positive labeled neurons was between 50 and $80 \%$, but the loss of $\alpha_{2}$-AR binding sites in the LC at the 50 and $70 \%$ levels of the LC is $\sim 18 \%$.

The number of positively labeled ${ }_{2 \mathrm{~A}} \mathrm{AR}$ mRNA neurons in the LC of $A D$ and DLB subjects is reduced, but expression per cell is not different from control subjects

To determine whether a change in mRNA is observed in the remaining neurons to account for the normal to modest reduc-
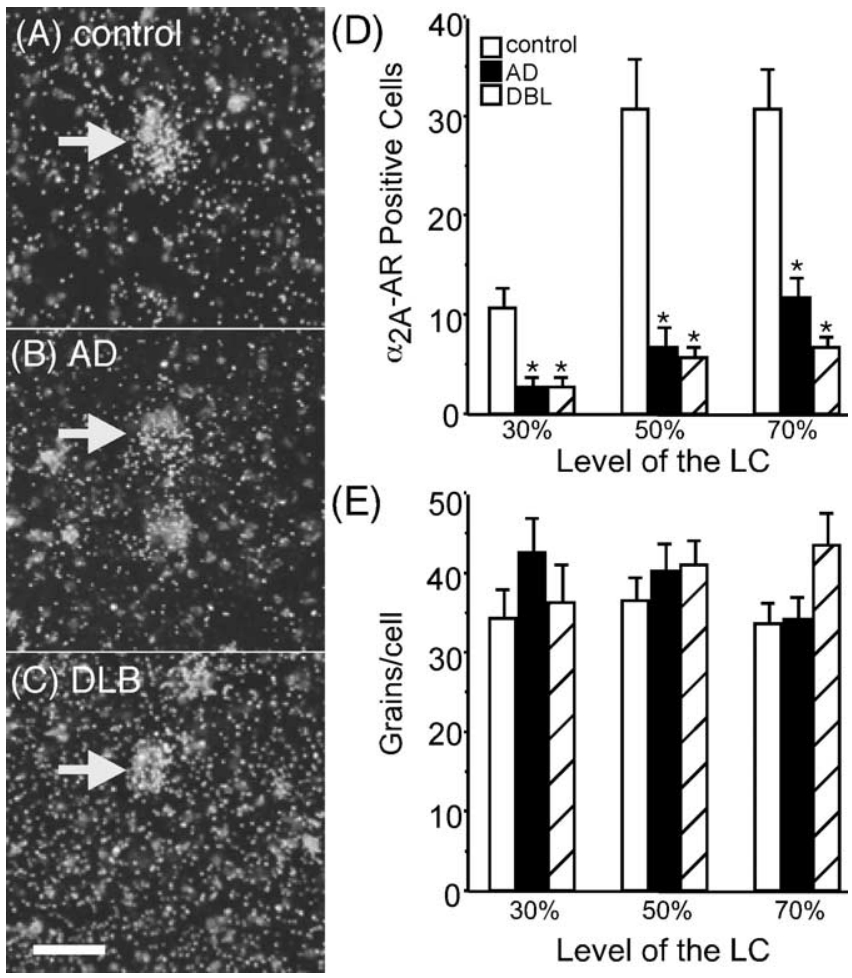

Figure 5. $\quad \alpha_{2 \mathrm{~A}}$-AR mRNA expression in the $\mathrm{LC}$ of control $(\boldsymbol{A})(n=15), \operatorname{AD}(\boldsymbol{B})(n=15)$, and DLB $(C)(n=15)$ subjects at the $50 \%$ level of the LC. The number of $\alpha_{2 A}$-AR mRNA-positive labeled neurons ( $\boldsymbol{D})$ and the amount of $\alpha_{2 \mathrm{~A}}$-AR mRNA expression per cell $(\boldsymbol{E})$ in the $\mathrm{LC}$ at the 30, 50 , and $70 \%$ levels of control, $A D$, and DLB subjects are shown. Filled arrows indicate a labeled neuron in each group. *Significant difference compared with control subjects. Scale bar, 100 $\mu \mathrm{m}$. Data are represented as mean $\pm \mathrm{SEM}$.

tion in $\alpha_{2}$-AR binding sites in AD and DLB subjects, in situ hybridization was performed for the $\alpha_{2 \mathrm{~A}}$-AR mRNA $\left(\alpha_{2 \mathrm{C}}-\mathrm{AR}\right.$ mRNA was not detected in the LC). $\alpha_{2 \mathrm{~A}}$-AR mRNA expression in LC neurons would be as the noradrenergic autoreceptor, which is responsible for ${ }^{3} \mathrm{H}$-RX821002 $\alpha_{2}$-AR binding observed within the $\mathrm{LC}$ and surrounding region. $\alpha_{2 \mathrm{~A}} \mathrm{AR}$ mRNA was expressed at all levels of the LC, but the level of $\alpha_{2 \mathrm{~A}}$-AR mRNA expression in the LC appeared to be lower (Fig. $5 A-C$ ) than that observed for TH mRNA expression (Fig. $1 A-C$ ). The number of $\alpha_{2 \mathrm{~A}}$-ARpositive labeled cell bodies that meet the criteria outlined in $\mathrm{Ma}$ terials and Methods (Fig. 5D) was lower than that observed for TH mRNA expression. For control subjects, the average number of $\alpha_{2 \mathrm{~A}}$-AR-positive labeled cells at the 30,50, and 70\% levels of the LC were 11, 31, and 31, respectively, whereas TH-positive labeled cells at these levels were 33, 79, and 90, respectively. Therefore, the number of $\alpha_{2 \mathrm{~A}}$-AR labeled cell bodies was 67, 61, and $66 \%$ reduced from $\mathrm{TH}$-positive labeled cells. AD and DBL subjects had a similar reduction of $\alpha_{2 \mathrm{~A}}$-AR-positive labeled cells in the $\mathrm{LC}, \mathrm{AD}$ subjects had 57,53 , and $70 \%$ reductions, whereas DBL subjects had 63,68 , and $71 \%$ reductions at the 30,50 , and $70 \%$ levels of the LC.

As observed with the number of TH-positive labeled neurons, both $\mathrm{AD}$ and $\mathrm{DLB}$ subjects had a significant reduction in the number of $\alpha_{2 \mathrm{~A}}$-AR-positive labeled cells compared with control subjects at the 30,50 , and $70 \%$ levels of the LC (Fig. 5D). The reduction in the number of $\alpha_{2 \mathrm{~A}}$-AR-labeled neurons was similar to what was observed with TH-positive labeled neurons. However, the amount of $\alpha_{2 \mathrm{~A}}$-AR mRNA expressed per cell in the remaining neurons in $\mathrm{AD}$ and $\mathrm{DLB}$ subjects was not significantly different from control subjects (Fig. 5E). There was a tendency 

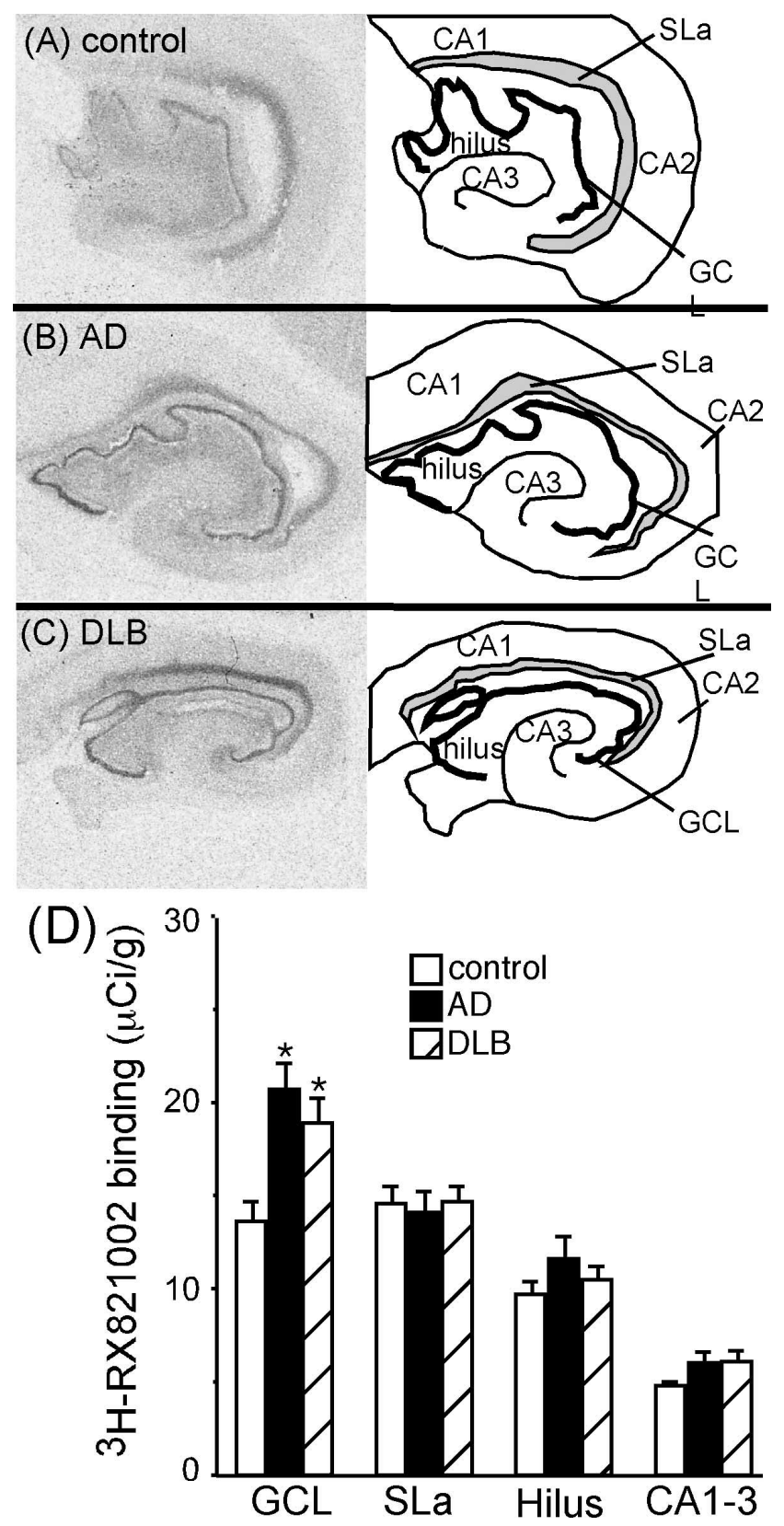

Figure 6. $\quad \alpha_{2}$-AR binding sites in the dorsal hippocampus of control $(\boldsymbol{A})(n=16), \mathrm{AD}(\boldsymbol{B})$ $(n=15)$, and DLB $(C)(n=21)$ subjects. The left side of the figure is the autoradiograms of ${ }^{3} \mathrm{H}-\mathrm{RX} 821002$ binding in the hippocampus. The right side outlines the areas labeled by ${ }^{3} \mathrm{H}$ RX821002 in the pyramidal cell layer (CA1-CA3), SLa, dentate gyrus GCL, and hilus. D, Quantification of $\alpha_{2}$-AR binding sites in the dorsal hippocampus in control, AD, and DLB subjects. *Significant difference compared with control subjects. Data are represented as mean \pm SEM.

for $\alpha_{2 \mathrm{~A}}-\mathrm{AR}$ mRNA expression per cell to be higher in $\mathrm{AD}$ and DLB subjects, but it did not reach statistical difference.

$\alpha_{2}$-AR binding sites in the hippocampus of AD and DLB are unchanged except for an increase in dentate gyrus granule cell layer

$\alpha_{2}$-AR binding sites were localized to the dentate gyrus granule cell layer (GCL), stratum lacunosum (SLa), hilus, and pyramidal cell layer of the CA1-CA3 (Fig. 6A-C). This binding pattern was similar to what has been observed previously in the human hippocampus (Pascual et al., 1992; Ordway et al., 1993; Leverenz et al., 2001). $\alpha_{2}$-AR binding sites are not statistically different be- tween control, AD, and DLB subjects in the SLa, hilus, and pyramidal cell layer, but, in the GCL, AD and DLB subjects had significantly more binding sites than control (Fig. $6 D$ ). The increase in $\alpha_{2}$-AR binding sites in the GCL was the same between $\mathrm{AD}$ and DLB subjects. $\alpha_{2}$-AR binding sites in the GCL of AD and DLB subjects did not correlate to the degree of dementia (Clinical Dementia Rating).

$\alpha_{2 \mathrm{~A}}$-AR mRNA expression in the hippocampus of $\mathrm{AD}$ and DLB subjects is not different from control subjects ${ }^{3} \mathrm{H}$-RX821002 binding sites in the human hippocampus represent mainly $\alpha_{2 \mathrm{~A}}$-ARs (Ordway et al., 1993; Sastre and GarciaSevilla, 1994), which are located both presynaptically and postsynaptically. To determine the contribution of postsynaptic $\alpha_{2 \mathrm{~A}}$-AR to the binding studies in the hippocampus, in situ hybridization to the $\alpha_{2 \mathrm{~A}}$-AR mRNA was performed. $\alpha_{2 \mathrm{~A}}$-AR mRNA was expressed at detectable but low levels in the GCL and CA3 region in all subjects (Fig. 7A-C). Quantitation of $\alpha_{2 \mathrm{~A}}$-AR mRNA in these regions in control, $\mathrm{AD}$, and DLB subjects was not statistically different (Fig. 7D).

$\alpha_{2 \mathrm{C}}$-AR mRNA expression in the hippocampus of AD and DLB subjects is significantly reduced in all regions compared with control subjects

$\alpha_{2 \mathrm{C}}$-AR mRNA expression in the human hippocampus was observed in the GCL, pyramidal cell layer (CA1-C3), and subiculum (Fig. $8 A-C$ ). Quantitation of $\alpha_{2 C^{-}}$AR mRNA in AD and DLB subjects was significantly reduced in all regions of the hippocampus compared with control subjects (Fig. 8D). The reduction in $\alpha_{2 \mathrm{C}}$-AR mRNA in the GCL, pyramidal cell layer, and subiculum was comparable between $\mathrm{AD}$ and DLB subjects. $\alpha_{2 \mathrm{C}} \mathrm{AR}$ mRNA expression in these regions did not correlate to the degree of dementia (Clinical Dementia Rating).

$\alpha_{1}$-AR binding sites in the hippocampus are elevated only in the molecular cell layer of the dentate gyrus of $\mathrm{AD}$ and DLB subjects

Unlike the $\alpha_{2}$-AR, the $\alpha_{1}$-AR is only localized postsynaptically. ${ }^{3} \mathrm{H}$-Prazosin binding sites in control, AD, and DLB showed a binding pattern (Fig. 9A-C) that was described previously in the human hippocampus (Szot et al., 2005). ${ }^{3} \mathrm{H}$-Prazosin labeled all three layers of the dentate gyrus (molecular, granular, and hilus) and the stratum lucidum. Quantitation of $\alpha_{1}$-AR binding sites in all three layers of the dentate gyrus in the three subject groups demonstrated a significant increase in $\mathrm{AD}$ and DLB subjects compared with controls (data not shown). On visual inspection of the autoradiograms (Fig. $9 A-C$ ), it was apparent that, in AD and DLB subjects, there was a greater amount of binding in the molecular cell layer. To determine whether ${ }^{3} \mathrm{H}$-prazosin binding sites were elevated in just the molecular cell layer in AD and DLB subjects, binding sites were quantitated over just the molecular cell layer and then over the GCL, hilus, and stratum lucidum (Fig. 9D). A significant increase in ${ }^{3} \mathrm{H}$-prazosin binding sites in the molecular cell layer was observed in AD and DLB subjects compared with control subjects, whereas in the GCL, hilus, and stratum lucidum, there was no difference between subjects groups. The increase in $\alpha_{1}$-AR binding sites in the molecular cell layer was not different between $\mathrm{AD}$ and DLB subjects (Fig. 9D). This indicates a selective increase in $\alpha_{1}$-AR binding sites in the hippocampus of $\mathrm{AD}$ and DLB subjects without a change in the other areas. $\alpha_{1}$-AR binding sites in the molecular cell layer of AD and DLB subjects did not correlate to the degree of dementia (Clinical Dementia Rating).

To rule out the possibility that the selective increase in $\alpha_{1}$-AR 

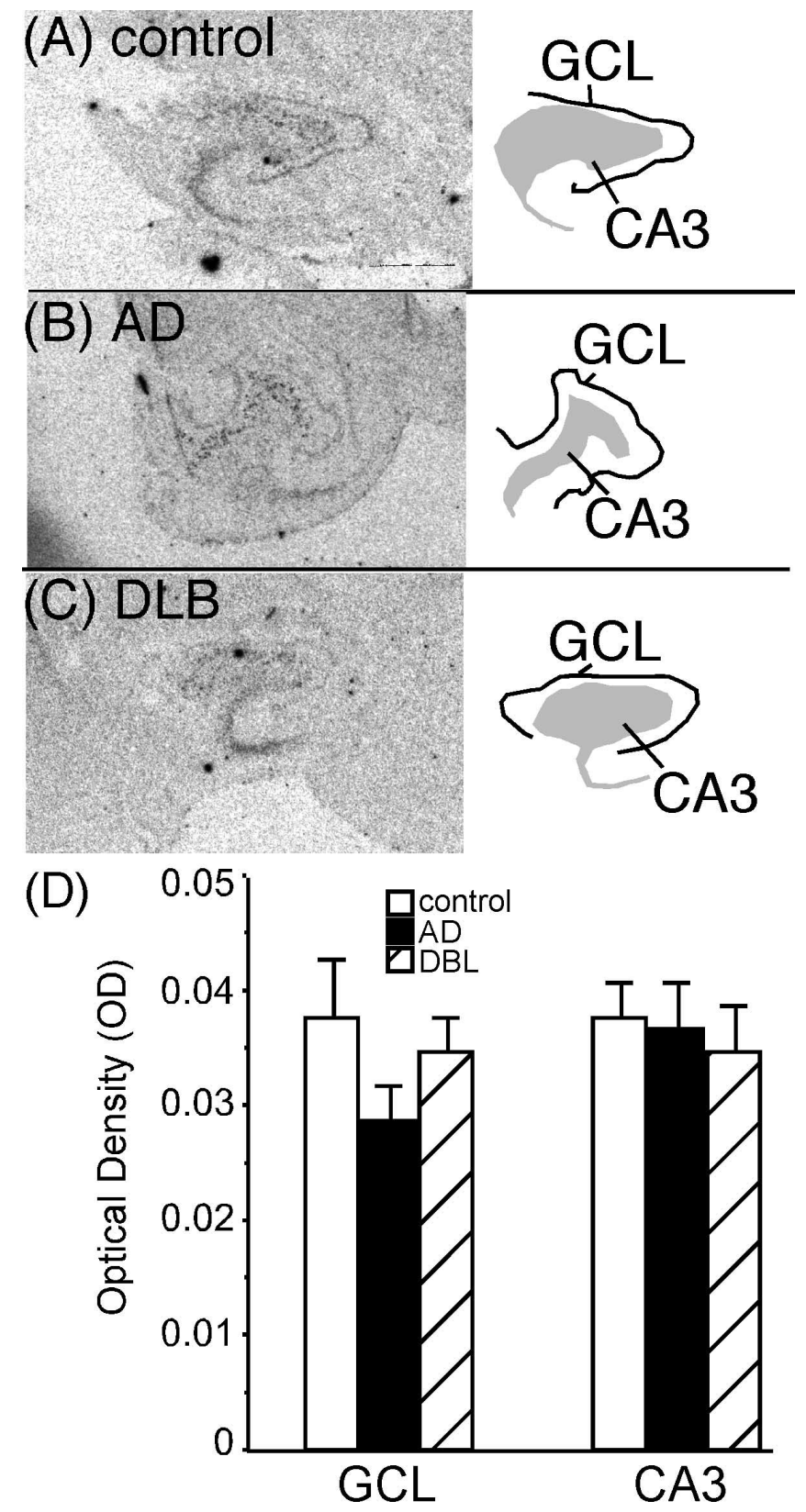

Figure 7. $\quad \alpha_{2 A}-A R$ mRNA expression in the dorsal hippocampus of control $(A)(n=16), A D$ $(\boldsymbol{B})(n=15)$, and $\mathrm{DLB}(\boldsymbol{C})(n=22)$ subjects. The left side of the figure are the autoradiograms of $\alpha_{2 A}-A R m R N A$. The right side outlines the area of $\alpha_{2 A}-A R m R N A$ expression in the pyramidal cell layer CA3, hilus, and dentate gyrus GCL. D, Quantification of $\alpha_{2 A}$-AR mRNA expression in the dorsal hippocampus in control, $A D$, and DLB subjects. Data are represented as mean \pm SEM.

binding sites in the molecular cell layer was a peculiarity of ${ }^{3} \mathrm{H}$ prazosin, another $\alpha_{1}$-AR antagonist was used. ${ }^{125}$ I-HEAT labeled exactly the same regions of the hippocampus as ${ }^{3} \mathrm{H}$-prazosin (data not shown). Quantitation of ${ }^{125} \mathrm{I}$-HEAT, similar to ${ }^{3} \mathrm{H}-$ prazosin, demonstrated a selective increase in ${ }^{125}$ I-HEAT binding sites in the molecular cell layer of $\mathrm{AD}$ and DLB subjects compared with control subjects (data not shown). No change was observed in the GCL, hilus, and stratum lucidum in the three subject groups (data not shown).

$\alpha_{1 \mathrm{~A}}$-AR mRNA expression in the GCL of AD and DLB subjects is not different from control subjects

$\alpha_{1 \mathrm{~A}}$-AR mRNA expression in the human hippocampus was observed only in the GCL (Szot et al., 2005) (Fig. 10A-C). Quanti-
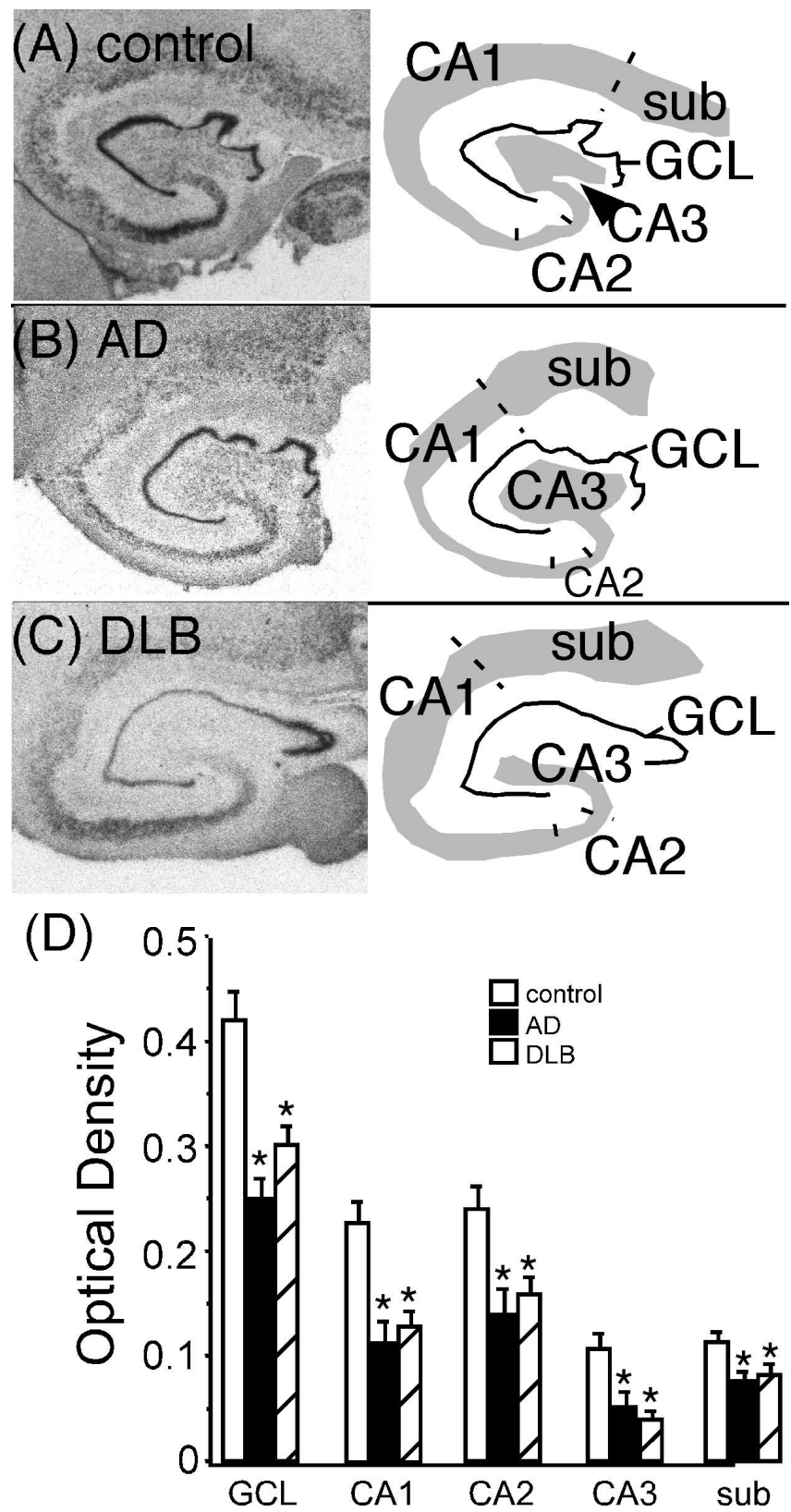

Figure 8. $\quad \alpha_{2 C}$ AR mRNA expression in the dorsal hippocampus of control $(\boldsymbol{A})(n=16), \mathrm{AD}$ $(\boldsymbol{B})(n=13)$, and $\operatorname{DLB}(\boldsymbol{C})(n=22)$ subjects. The left side of the figure are the autoradiograms of $\alpha_{2 C}$-AR mRNA. The right side outlines the area of $\alpha_{2 C}$-AR mRNA expression in the pyramidal cell layer (CA1-CA3), dentate gyrus GCL, and subiculum (sub). D, Quantification of $\alpha_{2 C}$-AR mRNA expression in the dorsal hippocampus in control, AD, and DLB subjects. *Significant difference compared with control subjects. Data are represented as mean \pm SEM.

tation of $\alpha_{1 \mathrm{~A}}$-AR mRNA expression in $\mathrm{AD}$ and DLB subjects in the GCL did not differ from control subjects (Fig. 10D).

$\alpha_{1 \mathrm{D}}-\mathrm{AR}$ mRNA expression in the pyramidal cell layer of $\mathrm{AD}$ and DLB subjects is significantly reduced from control subjects

$\alpha_{1 \mathrm{D}}$-AR mRNA was expressed only in the pyramidal cell layer as described previously (Szot et al., 2005) (Fig. 11A-C). Quantitation of $\alpha_{1 \mathrm{D}}$-AR mRNA expression in the pyramidal cell layer was significantly reduced in AD and DLB subjects compared with control subjects (Fig. $11 D$ ). The reduction in $\alpha_{1 \mathrm{D}}$-AR mRNA in $\mathrm{AD}$ and DLB subjects was similar. The reduction in $\alpha_{1 \mathrm{D}}$-AR 

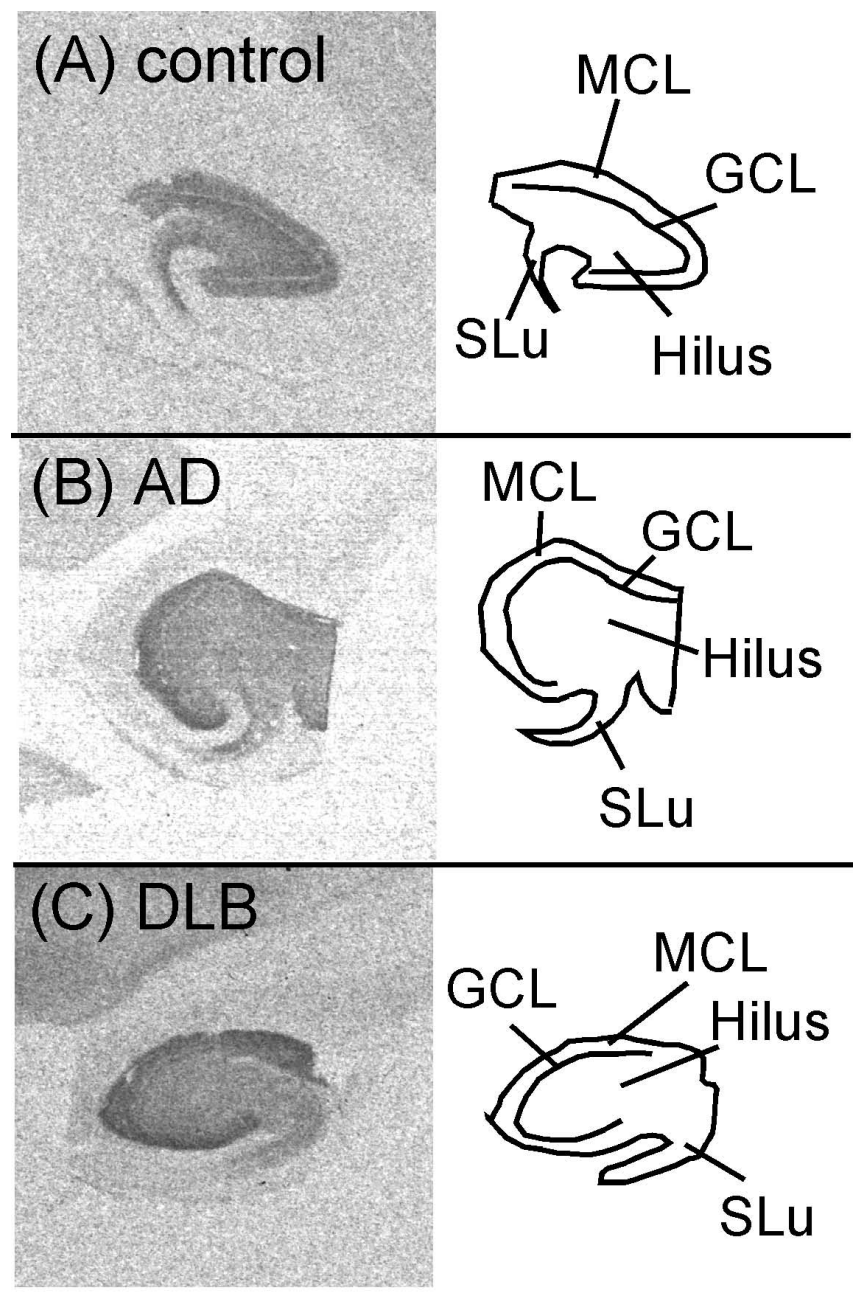

(D)

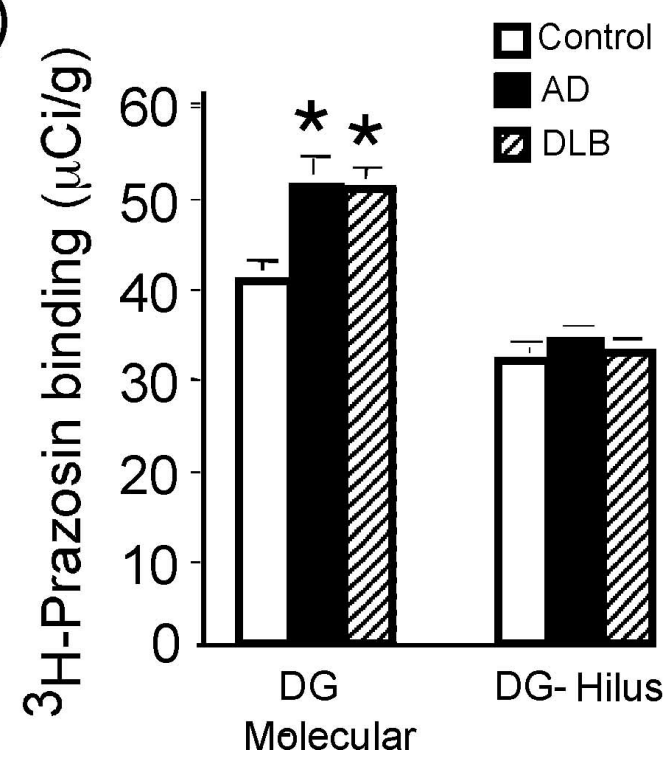

Figure 9. $\quad \alpha_{1}$-AR binding sites in the dorsal hippocampus of control $(\boldsymbol{A})(n=17), \mathrm{AD}(\boldsymbol{B})$ $(n=15)$, and $\operatorname{DLB}(C)(n=22)$ subjects. The left side of the figure is the autoradiograms of ${ }^{3} \mathrm{H}$-prazosin binding in the hippocampus. The right side outlines the areas labeled by ${ }^{3} \mathrm{H}-$ prazosin in the dentate gyrus, which is composed of the molecular cell layer (MCL), GCL and hilus, and the stratum lucidum (SLu). D, Quantification of $\alpha_{1}$-AR binding sites in the dorsal hippocampus in control, AD, and DLB subjects. DG, Dentate gyrus. *Significant difference compared with control subjects. Data are represented as mean \pm SEM.

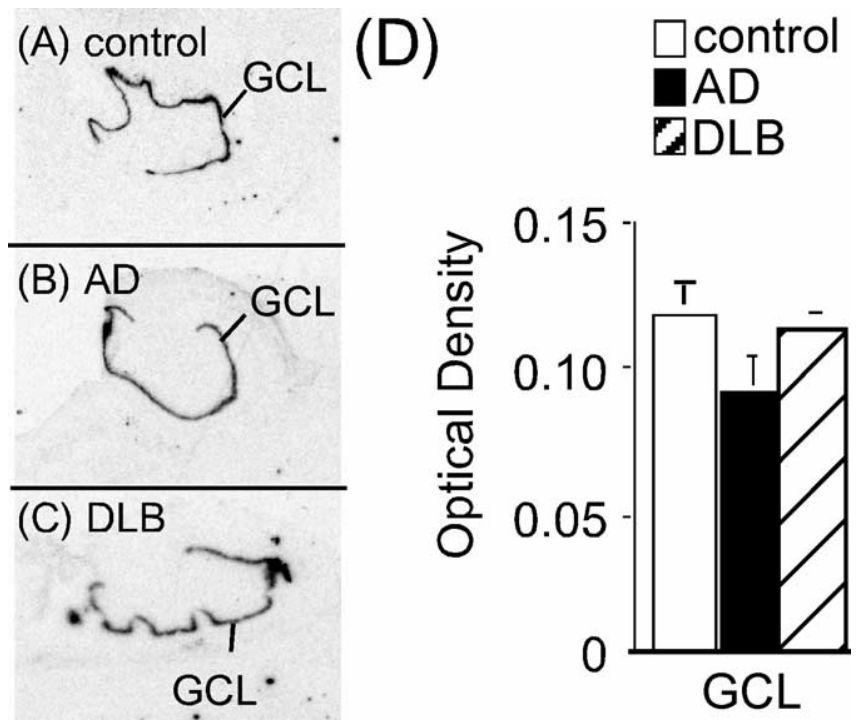

Figure 10. $\quad \alpha_{1 A}-A R m R N A$ expression in the dentate gyrus $\mathrm{GCL}$ of the dorsal hippocampus of control $(\boldsymbol{A})(n=17), \operatorname{AD}(\boldsymbol{B})(n=15)$, and DLB $(\boldsymbol{C})(n=22)$ subjects. $\boldsymbol{D}$, Quantification of $\alpha_{1 \mathrm{~A}}$-AR mRNA expression in the dorsal hippocampus in control, AD, and DLB subjects.
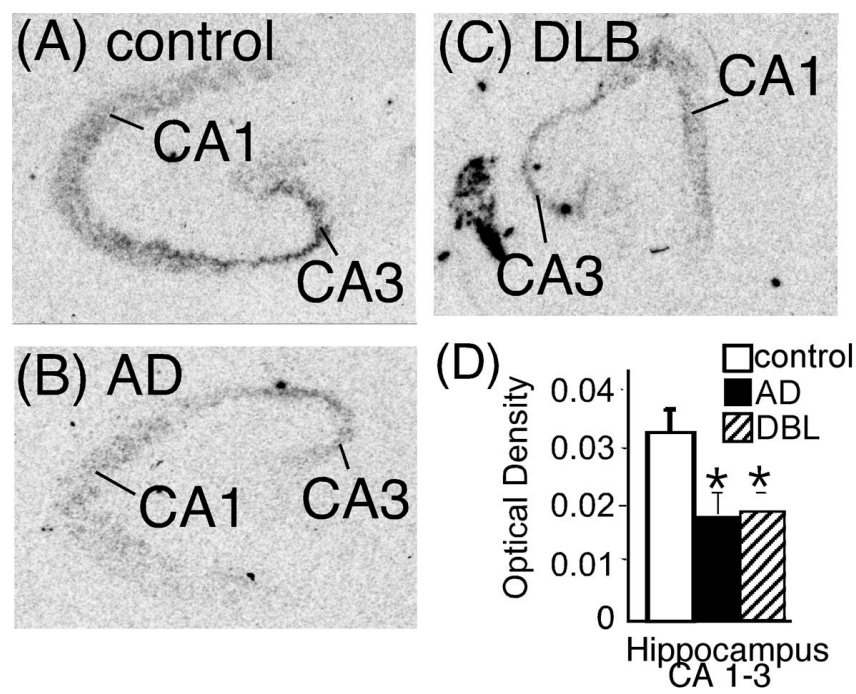

Figure 11. $\quad \alpha_{10}$-AR mRNA expression in the pyramidal cell layer (CA1-C3) of the dorsal hippocampus of control $(\boldsymbol{A})(n=17), \operatorname{AD}(\boldsymbol{B})(n=15)$, and $\operatorname{DLB}(\boldsymbol{C})(n=22)$ subjects. $\boldsymbol{D}$, Quantification of $\alpha_{10}$-AR mRNA expression in the dorsal hippocampus in control, AD, and DLB subjects. *Significant difference compared with control subjects. Data are represented as mean \pm SEM.

mRNA expression did not correlate to the degree of dementia (Clinical Dementia Ratings).

\section{Discussion}

In $\mathrm{AD}$ and the similar dementing disorder $\mathrm{DLB}$, there is a significant loss of noradrenergic neurons in the LC at multiple levels. This loss of neurons is documented at the molecular level with mRNA expression for TH, $\alpha_{2 \mathrm{~A}}-\mathrm{AR}$, and NET (Szot et al., 2000). The loss of neurons as measured by these mRNAs is very similar to the documented loss of noradrenergic neurons as measured by morphometric analysis (Marcyniuk et al., 1986; Chan-Palay and Asan, 1989; German et al., 1992). The degree of neuronal loss in $\mathrm{AD}$ subjects reported here is similar to our previously published work with a small subject population (Szot et al., 2000), and, as shown by Bondareff et al. (1981) and Matthews et al. (2002), the 
amount of TH-positive labeled neuronal loss correlates with the degree of cognitive loss. This correlation of noradrenergic neuronal loss to cognitive decline supports the importance of the noradrenergic system in learning and memory (Gibbs and Summers, 2002); however, how this neuronal loss contributes to cognitive loss is unclear at the present time. It needs to be determined whether the compensatory changes in the remaining neurons in the LC and at terminal projection sites such as the hippocampus and $\mathrm{CDR}$ contribute to the cognitive decline or could be used pharmacologically to enhance/restore memory.

In the present study, we performed a systematic molecular evaluation of the nature of this compensation. The first compensatory change in noradrenergic neurons is the significant increase in TH mRNA expression (rate-limiting enzyme in the synthesis of NE), which was observed at all levels of the LC. Differences in TH mRNA expression were observed between AD and DLB subjects (no other noradrenergic marker showed a significant difference between $\mathrm{AD}$ and DLB subjects). In DLB subjects, there is an even greater loss of $\mathrm{TH}$-positive labeled cell bodies at the $70 \%$ level of the LC compared with $\mathrm{AD}$, and, at the $50 \%$ level of the LC, DLB subjects have a greater expression of TH mRNA expression per cell. The increase in TH mRNA expression per cell corresponded to the loss of TH-positive labeled cells, i.e., the greater the degree of neuronal loss, the more TH mRNA expression per cell occurred. These studies, obviously, do not indicate whether the amount of NE released in forebrain structures is normal but support previous reports of normal to elevated levels of CSF NE and NE metabolites compared with age-matched control subjects (Mann et al., 1981; Gottfries et al., 1983; Raskind et al., 1984; Tohgi et al., 1992; Elrod et al., 1997).

The second type of compensatory change is observed with the dendritic innervation of the LC neurons to the peri-LC dendritic zone. The $\mathrm{LC}$ receives a vast amount of afferent projections, but the majority of these fibers do not go directly to the LC cell body region; rather they innervate the surrounding LC region (AstonJones et al., 2004) termed the peri-LC dendritic zone. NET binding sites are localized over the LC cell body region (Bauer and Tejani-Butt, 1992; Tejani-Butt et al., 1993) and over the peri-LC dendritic region, with the greater density over the LC cell body region. The significant loss of NET binding sites over the LC cell body region in $\mathrm{AD}$ and $\mathrm{DLB}$ can be attributed to the loss of $\mathrm{LC}$ neurons, as noted by Tejani-Butt et al. (1993). However, the normal amount of NET binding sites in the peri-LC dendritic zone of $\mathrm{AD}$ and DLB subjects suggests that the remaining noradrenergic neurons are sprouting dendritic connections into the surrounding $\mathrm{LC}$ region in an attempt to maintain synaptic connections. This is also supported by the findings with the $\alpha_{2}$-AR autoreceptor. The density of this autoreceptor is reduced in $\mathrm{AD}$ and DLB subjects at certain levels of the LC, but the loss is not as extensive as that observed with neuronal number, supporting the hypothesis of dendritic sprouting. The consequence of the loss of this autoreceptor may be increased firing of noradrenergic neurons and release of NE in the LC and at terminal regions (L'Heureux et al., 1986; Van Gaalen et al., 1997; Kawahara et al., 1999).

Expression of NET (Szot et al., 2000) or $\alpha_{2 \mathrm{~A}}$-AR mRNA in the remaining noradrenergic neurons in $\mathrm{AD}$ and $\mathrm{DLB}$ subjects is not elevated, so it is unclear what factors are involved in maintaining the normal NET and $\alpha_{2}$-AR binding sites in the LC. Animal work does not indicate what may occur to the expression of NET or $\alpha_{2 \mathrm{~A}}$-AR mRNA in LC neurons after lesioning noradrenergic neurons because it has not been studied. One explanation for the lack of a significant change in NET or $\alpha_{2 \mathrm{~A}}$-AR mRNA expression in the remaining noradrenergic neurons is a change in the stability of the transcript or receptor protein.

The third type of compensatory change in noradrenergic neurons is with axonal projections. The normal amount of NET binding sites in the cDR and normal to elevated $\alpha_{2}$-ARs in the hippocampus of $\mathrm{AD}$ and $\mathrm{DLB}$ subjects indicate that remaining noradrenergic neurons are demonstrating axonal sprouting. Several studies have examined $\alpha_{2}$-ARs in the hippocampus of AD subjects using autoradiography and membrane binding studies with many different radiolabeled ligands. The results have been conflicting: either a significant decrease (Meana et al., 1992; Pascual et al., 1992) or no change or an increase were observed (Leverenz et al., 2001; Matthews et al., 2002).

Because $\alpha_{2}$-ARs in the hippocampus may be a composite of the autoreceptor and postsynaptic receptors (including heterore-

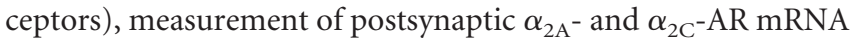
expression was performed, and another postsynaptic AR $\left(\alpha_{1}-\mathrm{AR}\right)$ was measured in the hippocampus. $\alpha_{2 \mathrm{~A}}$-AR (the subtype responsible for ${ }^{3} \mathrm{H}$-RX821002 binding sites) (Ordway et al., 1993; Sastre and Garcia-Sevilla, 1994) mRNA expression in the hippocampus of $\mathrm{AD}$ and $\mathrm{DLB}$ subjects was not different from controls, suggesting that postsynaptic $\alpha_{2 \mathrm{~A}}$-AR sites are also normal in AD and DLB subjects.

In contrast to $\alpha_{2 \mathrm{~A}}$-AR mRNA expression, $\alpha_{2 \mathrm{C}}$-AR mRNA expression in the hippocampus of $\mathrm{AD}$ and $\mathrm{DLB}$ subjects was significantly reduced. Because binding studies with ${ }^{3} \mathrm{H}-\mathrm{RX} 821002$ do not reflect the changes in this receptor subtype, the functional consequence of this reduced mRNA expression is unclear. Loss of $\alpha_{2 \mathrm{C}}-\mathrm{AR}$, as observed in transgenic mice $\left(\alpha_{2 \mathrm{C}}-\mathrm{AR}\right.$ knock-out mice), results in many behavioral changes, including increased stress and startle response, and locomotion (Sallinen et al., 1997). Interestingly, agitation and pacing are common behavioral symptoms in dementia patients. Perhaps the loss of $\alpha_{2 \mathrm{C}}$-AR mRNA in AD and DLB subjects in the hippocampus contributes to these behavior symptoms. The loss of $\alpha_{2}$-AR mRNA in the GCL or CA3 cannot be attributed to neuronal loss in AD because these regions do not demonstrate any degree of loss (Simic et al., 1997; Bobinski et al., 1998; Fukutani et al., 2000; Price et al., 2001; Rossler et al., 2002), and the expression of $\alpha_{2 \mathrm{~A}}$-AR mRNA in the same regions was unchanged in $\mathrm{AD}$ and DLB.

Postsynaptic $\alpha_{1}$-AR binding sites in the hippocampus of $\mathrm{AD}$ and DLB subjects are normal to elevated, indicating an intact postsynaptic system. Previous $\alpha_{1}$-AR binding studies in the hippocampus of $\mathrm{AD}$ subjects demonstrated either a decrease in binding with ${ }^{3} \mathrm{H}$-prazosin (Shimohama et al., 1986) or no change with ${ }^{125}$ I-HEAT (Kalaria, 1989). These previously published studies used a homogenous membrane preparation from the whole hippocampus. This method would not allow the differentiation of the different layers of the hippocampus (i.e., molecular cell layer from dentate gyrus), and measurement would include both membrane and cytoplasmic material. Because the $\alpha_{1}$-AR protein may be localized in both the membrane and cytoplasm (MacKenzie et al., 2000; Piascik and Perez, 2001; halothorn et al., 2002), it is likely that homogenizing the tissue would affect the number of available receptors for the $\alpha_{1}$-AR ligand to bind to relative to slice preparation. The increase in $\alpha_{1}$-AR binding in AD and DLB subjects is not explained by the expression of $\alpha_{1 \mathrm{~A}^{-}}$or $\alpha_{1 \mathrm{D}}$-AR mRNA. Because $\alpha_{1 \mathrm{~A}}$-AR contributes mainly to ${ }^{3} \mathrm{H}$ prazosin binding sites in the human hippocampus (Szot et al., 2005), the lack of a change in $\alpha_{1 \mathrm{~A}}$-AR mRNA in AD and DLB subjects indicate that the increase does not appear to be the result of increased mRNA expression but may represent a change in transcript or protein stability, or sprouting of the dendrites from 
GCL neurons into the molecular cell layer. Sprouting of GCL neurons has been shown to occur in AD subjects (Cassell and Brown, 1984; Dickson et al., 1994).

$\alpha_{1 \mathrm{D}}$-AR mRNA, the other major CNS $\alpha_{1}$-AR subtype, was significantly reduced in both $\mathrm{AD}$ and DLB subjects. The reduction in $\alpha_{1 \mathrm{D}}$-AR mRNA cannot be attributed to the cell loss documented in the CA1 in AD (Simic et all., 1997; Bobinski et al., 1998; Fukutani et al., 2000; Price et al., 2001; Rossler et al., 2002) because $\alpha_{2 \mathrm{~A}}$-AR mRNA expression was unchanged in the same region, in the same subjects. It is possible that these different $\alpha$-AR subtypes are expressed in different neurons and the neurons expressing $\alpha_{1 \mathrm{D}}-\mathrm{AR}$ mRNA are lost in AD and DLB. The consequence of reduced $\alpha_{1 \mathrm{D}}$-AR mRNA expression for protein levels cannot be determined at this time because none of the existing $\alpha_{1}$-AR ligands bind to this receptor subtype. However, loss of $\alpha_{1 \mathrm{D}}$-AR mRNA in pyramidal neurons, especially CA1 neurons, suggests the loss of the modulation of NE on hippocampal pathways. It is interesting to note that $\alpha_{2 \mathrm{C}}$-AR mRNA expression is also reduced in these AD and DLB subjects in a similar region. A common factor between these two AR subtypes compared with $\alpha_{1 \mathrm{~A}^{-}}$and $\alpha_{2 \mathrm{~A}^{-}} \mathrm{AR}$ mRNA (which are unchanged in AD and DLB subjects) is that $\alpha_{1 \mathrm{D}^{-}}$and $\alpha_{2 \mathrm{C}^{-}}$ARs are intracellular receptors, whereas $\alpha_{1 \mathrm{~A}^{-}}$and $\alpha_{2 \mathrm{~A}^{-}} \mathrm{AR}$ are membrane-bound receptors (Daunt et al., 1997; MacKenzie et al., 2000; Piascik and Perez, 2001; Chalothorn et al., 2002).

In conclusion, after the loss of noradrenergic neurons in $\mathrm{AD}$ and DLB, three major compensatory changes are observed in the noradrenergic nervous system: (1) an increase per neuron in mRNA for TH, the rate-limiting enzyme in the synthesis of NE; (2) sprouting of dendrites of the remaining LC neurons to the peri-LC dendritic area; and (3) sprouting of LC axons to CDR and hippocampus. Also, other noradrenergic markers are not normal: $\alpha_{1 D^{-}}$and $\alpha_{2 C^{-}}$AR mRNA expression in the hippocampus of $\mathrm{AD}$ and $\mathrm{DLB}$ subjects are significantly reduced. For all noradrenergic markers, there was no difference between $\mathrm{AD}$ and $\mathrm{DLB}$ subjects except for minor differences in TH mRNA expression; therefore, the presence of Lewy bodies in addition to plaques and tangles in DLB subjects does not appear to further affect the noradrenergic compensatory changes.

\section{References}

Adolfsson R, Gottfries CG, Roos BE, Winblad B (1979) Changes in the brain catecholamines in patients with dementia of Alzheimer's type. Br J Psychiatry 135:216-223.

Aston-Jones G, Zhu Y, Card JP (2004) Numerous GABAergic afferents to locus ceruleus in the pericerulear dendritic zone: possible interneuronal pool. J Neurosci 24:2313-2321.

Ballard C, Holmes C, McKeith I, Neill D, O'Brien J, Cairns N, Lantos P, Perry E, Ince P, Perry R (1999) Psychiatric morbidity in dementia with Lewy bodies: a prospective clinical and neuropathological comparative study with Alzheimer's disease. Am J Psychiatry 156:1039-1045.

Barber R, Panikkar A, McKeith IG (2001) Dementia with Lewy bodies: diagnosis and management. Int J Geriatr Psychiatry 16:S12-S18.

Bauer ME, Tejani-Butt SM (1992) Effects of repeated administration of desipramine or electroconvulsive shock on norepinephrine uptake sites measured by $\left[{ }^{3} \mathrm{H}\right]$ nisoxetine autoradiography. Brain Res 582 : $208-214$.

Bobinski M, de Leon MJ, Tarnawski M, Wegiel J, Bobinski M, Reisberg B, Miller DC, Wisniewski HM (1998) Neuronal and volume loss in CAl of the hippocampal formation uniquely predicts duration and severity of Alzheimer's disease. Brain Res 805:267-269.

Bondareff W, Mountjoy CQ, Roth M (1981) Selective loss of neurons of origin of adrenergic projection to cerebral cortex (nucleus locus coeruleus) in senile dementia. Lancet 1:783-784.

Bondareff W, Mountjoy CQ, Roth M (1982) Loss of neurons of origin of the adrenergic projection to cerebral cortex (nucleus locus ceruleus) in senile dementia. Neurology 32:164-168.
Cassell MD, Brown MW (1984) The distribution of Timm's stain in the nonsulfide-perfussed human hippocampal formation. J Comp Neurol 222:461-471.

Chalothorn D, McCune DF, Edelmann SE, Garcia-Cazarin ML, Tsujimoto G, Piascik MT (2002) Differences in the cellular localization and agonistmediated internatization properties of the $\alpha_{1}$-adrenoceptor subtypes. Mol Pharmacol 61:1008-1016.

Chan-Palay V, Asan E (1989) Alterations in catecholamine neurons of the locus coeruleus in senile dementia of the Alzheimer's type and in Parkinson's disease with and without dementia and depression. J Comp Neurol 287:373-392.

Cross AJ, Crow TJ, Perry EK, Perry RH, Blessed G, Tomlinson BE (1981) Reduced dopamine-beta-hydroxylase activity in Alzheimr's disease. $\mathrm{Br}$ Med J (Clin Res Ed) 282:93-94.

Daunt DA, Hurt C, Hein L, Kallio J, Feng F, Kobilka BK (1997) Subtypespecific intracellular trafficking of $\alpha_{2}$-adrenrgic receptors. Mol Pharmacol 51:711-720.

Dickson DW, Davies P, Bevona C, Van Hoeven KH, Factor SM, Grober E, Aronson MK, Crystal HA (1994) Hippocampal sclerosis: a common pathological feature of dementia in the very old ( $>$ or $=80$ years of age) human. Acta Neuropathol 88:212-221.

Elrod R, Peskind ER, DiGiacomo L, Brodkin KL, Veith RC, Raskind MA (1997) Effects of Alzheimer's disease severity on cerebrospinal fluid norepinephrine concentration. Am J Psychiatry 154:25-30.

Fallon JH, Loughlin SE (1982) Monoamine innervation of the forebrain: collateralization. Brain Res Bull 9:295-307.

Fraser CM, Arakawa S, McCombie WR, Venter JC (1989) Cloning, sequence analysis, and permanent expression of a human $\alpha_{2}$-adrenergic receptor in Chinese hamster ovary cells. Evidence for independent pathways of receptor coupling to adenylate cyclase attenuation and activation. J Biol Chem 264:11754-11761.

Fukutani Y, Cairns NJ, Shiozawa M, Sasaki K, Sudo S, Isaki K, Lantos PL (2000) Neuronal loss and neurofibrillary degeneration in the hippocampal cortex in late-onset sporadic Alzheimer's disease. Psychiatry Clin Neurosci 54:523-529.

German DC, Manaye KF, White CL, Woodward DJ, McIntire DD, Smith WK, Kalaria RN, Mann DM (1992) Disease-specific patterns of locus coeruleus cell loss. Ann Neurol 32:667-676.

Gibbs ME, Summers RJ (2002) Role of adrenoceptor subtypes in memory consolidation. Prog Neurobiol 67:345-391.

Gottfries CG, Adolfsson R, Aquilonius SM, Carlsson A, Eckernas SA, Nordberg A, Oreland L, Svennerholm L, Wiberg A, Winblad B (1983) Biochemical changes in dementia disorders of Alzheimer's type (AD/SDAT). Neurobiol Aging 4:261-271.

Happe HK, Coulter CL, Gerety ME, Sanders JD, O’Rourke M, Bylund DB, Murrin LC (2004) Alpha-2 adrenergic receptor development in rat CNS: an autoradiographic study. Neuroscience 123:167-178.

Harro J, Oreland L (2001) Depression as a spreading adjustment disorder of monoaminergic neurons: a case for primary implication of the locus coeruleus. Brain Res Rev 38:79-128.

Hirasawa A, Horie K, Tanaka T, Takagaki K, Murai M, Yano J, Tsujimoto G (1993) Cloning, functional expression and tissue distribution of human cDNA for the $\alpha_{1 \mathrm{C}}$-adrenergic receptor. Biochem Biophys Res Comm 195:902-909.

Homma N, Hirasawa A, Shibata K, Hashimito K, Tsujimoto G (2000) Both $\alpha_{1 \mathrm{~A}}$ and $\alpha_{1 \mathrm{~B}}$-adrenrgic receptor subtypes couple to the transient outward subtype current $\left(\mathrm{I}_{\mathrm{To}}\right)$ in rat ventricular myocytes. Br J Pharmacol 129:1113-1120.

Hoogendijk WJ, Freenstra MG, Botterblom MH, Gilhuis J, Sommer IE, Kamphorst W, Eikelenboom P, Swaab DF (1999) Increased activity of surviving locus ceruleus neurons in Alzheimer's disease. Ann Neurol 45:82-91.

Kalaria RN (1989) Characterization of [ $\left.{ }^{125} \mathrm{I}\right]$ HEAT binding to $\alpha_{1}$-receptors in human brain: assessment in aging and Alzheimer's disease. Brain Res 501:287-294.

Kawahara Y, Kawahara H, Westerink BHC (1999) Tonic regulation of the activity of noradrenrgic neurons in the locus coeruleus of the conscious rat: studies by dual-probe microdialysis. Brain Res 823:42-48.

Kobilka BK, Matsui H, Kobilka TS, Yang-Feng TL, Francke U, Caron MG, Lefkowitz RJ, Regan JW (1987) Cloning, sequencing, and expression of the gene coding for the human platelet $\alpha_{2}$-adrenergic receptor. Science 238:650-656. 
Lacroix D, Blier P, Curet O, de Montigny C (1991) Effects of long term desipramine administration on noradrenergic neurotransmission: electrophysiological studies in the rat brain. J Pharmacol Exp Ther 257:1081-1091.

Leverenz JB, Miller MA, Dobie DJ, Peskind ER, Raskind MA (2001) Increased alpha 2-adrenergic receptor binding in locus coeruleus projection areas in dementia with Lewy bodies. Neurobiol Aging 22:555-561.

L'Heureux R, Dannis T, Curet O, Scatton B (1986) Measurement of endogenous noradrenaline release in the rat cerebral cortex in vivo by transcortical dialysis: effect of drugs affecting noradrenergic transmission. J Neurochem 46:1794-1801.

Lomasney JW, Lorenz W, Allen LF, King K, Regan JW, Yang-Feng TL, Caron MG, Lefkowitz RJ (1990) Expansion of the $\alpha_{2}$-adrenergic receptor family: cloning and characterization of a human $\alpha_{2}$-adrenergic receptor subtype, the gene for which is located on chromosome 2. Proc Natl Acad Sci USA 87:5094-5098.

Loughlin SE, Foote SL, Fallon JH (1982) Locus coeruleus projections to cortex: topography, morphology and collateralizations. Brain Res Bull 9:287-294.

MacKenzie JF, Daly CJ, Pediani JD, McGrath JC (2000) Quantitative imaging in live human cells reveals intracellular $\alpha_{1}$-adrenoreceptor ligandbinding sites. J Pharmacol Exp Ther 294:434-443.

Mann DM, Lincoln J, Yates PO, Stamp JE, Toper S (1980) Changes in the monoamine containing neurons of the human CNS in senile dementia. Br J Psychiatry 136:533-541.

Mann JJ, Stanley M, Neophytides A, de Leon MJ, Ferris SH, Gershon S (1981) Central amine metabolism in Alzheimer's disease: in vivo relationship to cognitive deficit. Neurobiol Aging 2:57-60.

Marcyniuk B, Mann DM, Yates PO (1986) Loss of nerve cells from locus coeruleus in Alzheimer's disease is topographically arranged. Neurosci Lett 64:247-252.

Matthews KL, Chen CPL-H, Esiri MM, Keene J, Minger SL, Francis PT (2002) Noradrenergic changes, aggressive behavior, and cognition in patients with dementia. Biol Psychiatry 51:407-416.

McKeith IG, Galasko D, Kosaka K, Perry EK, Dickson DW, Hansen LA, Salmon DP, Lowe J, Mirra SS, Byrne FJ, Lennox G, Quinn NP, Edwardson JA, Ince PG, Bergeron C, Burns A, Miller BL, Lovestone S, Collerton D, Jansen EN, et al. (1996) Consensus guidelines for the clinical and pathologic diagnosis of dementia with Lewy bodies (DLB): report of the consortium on DLB international workshop. Neurology 47:1113-1124.

McKhann G, Drachman D, Folstein M, Katzman R, Price D, Stadlam EM (1984) Clinical diagnosis of Alzheimer's disease: report of the NINCDSADRDA Work Group under the auspices of Department of Health and Human Services Task Force on Alzheimer's disease. Neurology 34:939-944.

Meana JJ, Barturen F, Garro MA, Garcia-Sevilla JA, Fontan A, Zarranz JJ (1992) Decreased density of pre-synaptic $\alpha_{2}$-adrenoceptors in postmortem brains of patients with Alzheimer's disease. J Neurochem 58:1896-1904.

Morris RG, Moser EI, Riedel G, Martin SJ, Sandin J, Day M, O'Carroll C (2003) Elements of a neurobiological theory of the hippocampus: the role of activity-dependent synaptic plasticity in memory. Philos Trans Soc Lond B Biol Sci 358:773-786.

O’Malley KL, Anhalt MJ, Martin BM, Kelsoe JR, Winfield SL, Ginns EJ (1987) Isolation and characterization of the human tyrosine hydroxylase gene: identification of $5^{\prime}$ alternative splice sites responsible for multiple mRNAs. Biochemistry 26:6910-6914.

Ordway GA, Jaconetta SM, Halaris AE (1993) Characterization of subtypes of alpha-2 adrenoreceptors in the human brain. J Pharmacol Exp Ther 264:967-976.

Ordway GA, Schenk J, Stockmeier CA, May W, Klimek V (2003) Elevated agonist binding to $\alpha_{2}$-adrenoceptors in the locus coeruleus in major depression. Biol Psychiatry 53:315-323.

Palmer AM, Wilcock GK, Esiri MM, Francis PT, Bowen DM (1987) Monoaminergic innervation of the frontal and temporal lobes in Alzheimer's disease. Brain Res 401:231-238.

Pascual J, Grijalba B, Garcia-Sevilla JA, Zarranz JJ, Pazos A (1992) Loss of high-affinity $\alpha_{2}$-adrenoceptors in Alzheimer's disease: an autoradiographic study in frontal cortex and hippocampus. Neurosci Lett 142:36-40.

Perry EK, Blessed G, Tomlinson BE, Perry RH, Crow TJ, Cross AJ, Dockray GJ, Dimaline R, Arregui A (1981) Neurochemical activities in human temporal lobe related to aging and Alzheimer-type changes. Neurobiol Aging 2:251-256.

Piascik M, Perez DM (2001) $\alpha_{1}$-Adrenergic receptors: New insights and directions. J Pharmacol Exp Ther 298:403-410.

Price JL, Ko AL, Wade MJ, Tsou SK, Mckeel DW, Morris JC (2001) Neuron number in the entorhinal cortex and CA1 in preclinical Alzheimer's disease. Arch Neurol 58:1395-1402.

Raskind MA, Peskind ER, Halter JB, Jimerson DC (1984) Norepinephrine and MHPG levels in CSF and plasma in Alzheimer's disease. Arch Gen Psychiatry 41:343-346.

Reinikainen KJ, Paljarvi L, Huuskonen M, Soininen H, Laakso M, Reikkinen P (1988) A post-mortem study of noradrenergic, serotonergic and GABAergic neurons in Alzheimer's disease. J Neurol Sci 84:101-116.

Rossler M, Zarski R, Bohl J, Ohm TG (2002) Stage-dependent and sectorspecific neuronal loss in hippocampus during Alzheimer's disease. Acta Neuropathol 103:363-369.

Russo-Neustadt A, Zomorodian TJ, Cotman CW (1998) Preserved cerebellar tyrosine hydroxylase-immunoreactive neuronal fibers in a behaviorally aggressive subgroup of Alzheimer's disease patients. Neuroscience 87:55-61.

Sallinen J, Link RE, Haapalinna A, Viitamaa T, Kulatunga M, Sjoholm B, MacDonald E, Pelto-Huikko M, Leino T, Barsh GS, Kobilka BK, Scheinin M (1997) Genetic alteration of $\alpha_{2 C}$-adrenoceptor expression in mice: influence on locomotor, hypothermic, and neurochemical effects of dexmedetomidine, a subtype-nonselective $\alpha_{2}$-adrenoceptor agonist. Mol Pharmacol 51:36-46.

Sastre M, Garcia-Sevilla JA (1994) Alpha 2-adrenoceptor subtypes identified by [3H]RX821002 binding in the human brain: the agonist guanoxabenz does not discriminate different forms of the predominant alpha $2 \mathrm{~A}$ subtype. J Neurochem 63:1077-1085.

Schwinn DA, Lomasney JW, Lorenz W, Szklut PJ, Fremeau RT, Yang-Feng TL, Caron MG, Lefkowitz RJ, Cotecchis S (1990) Molecular cloning and expression of the cDNA for a novel $\alpha_{1}$-adrenergic receptor subtype. J Biol Chem 265:8183-8189.

Schwinn DA, Johnston GI, Page SO, Mosley MJ, Wilson KH, Worman NP, Campbell S, Fidock MD, Furness LM, Parry-Smith DJ, Peter B, Bailey DS (1995) Cloning and pharmacological characterization of human alpha-1 adrenergic receptors: sequence corrections and direct comparison with other species homologues. J Pharmacol Exp Ther 272:134-142.

Shimohama S, Taniguchi T, Fujiwara M, Kameyama M (1986) Biochemical characterization of $\alpha$-adrenergic receptors in human brain and changes in Alzheimer-type dementia. J Neurochem 47:1295-1301.

Simic G, Kostovic I, Winblad B, Bogdanovic N (1997) Volume and number of neurons of the human hippocampal formation in normal aging and Alzheimer's disease. J Comp Neurol 379:482-494.

Szot P, White SS, Veith RC (1997) Effect of pentylenetetrazol on the expression of tyrosine hydroxylase mRNA and norepinephrine and dopamine transporter mRNA. Mol Brain Res 44:46-54.

Szot P, Leverenz JB, Peskind ER, Kiyasu E, Rohde K, Miller MA, Raskind MA (2000) Tyrosine hydroxylase and norepinephrine transporter mRNA expression in the locus coeruleus in Alzheimer's disease. Mol Brain Res 84:135-140.

Szot P, White SS, Greenup JL, Leverenz JB, Peskind ER, Raskind MA (2005) $\alpha_{1}$-adrenoreceptor in human hippocampus: Binding and receptor subtype mRNA expression. Mol Brain Res 139:367-371.

Tejani-Butt SM, Yang J, Zaffer H (1993) Norepinephrine transporter sites are decreased in the locus coeruleus in Alzheimer's disease. Brain Res 631:147-150.

Tohgi H, Ueno M, Abe T, Takahashi S, Nozaki Y (1992) Concentrations of monoamines and their metabolites in the cerebral spinal fluid from patients with senile dementia of the Alzheimer's type and vascular dementia of the Binswanger's type. J Neurol Transm Park Dis Dement Sect 4:69-77.

Tomlinson BE, Irving D, Blessed G (1981) Cell loss in the locus coeruleus in senile dementia of the Alzheimer's type. J Neurol Sci 49:419-428.

Van Gaalen M, Kawahara H, Kawahara Y, Westerink BHC (1997) The locus coeruleus noradrenrgic system in the rat brain studied by dual-probe microdialysis. Brain Res 763:56-62.

Weinberg DH, Trivedi P, Tan CP, Mitra S, Perkins-Barrow A, Borkowski D, Strader CD, Bayne M (1994) Cloning, expression and characterization of human $\alpha$ adrenergic receptors $\alpha_{1 \mathrm{~A}}, \alpha_{1 \mathrm{~B}}$ and $\alpha_{1 \mathrm{C}}$. Biochem Biophys Res Commun 201:1296-1304. 